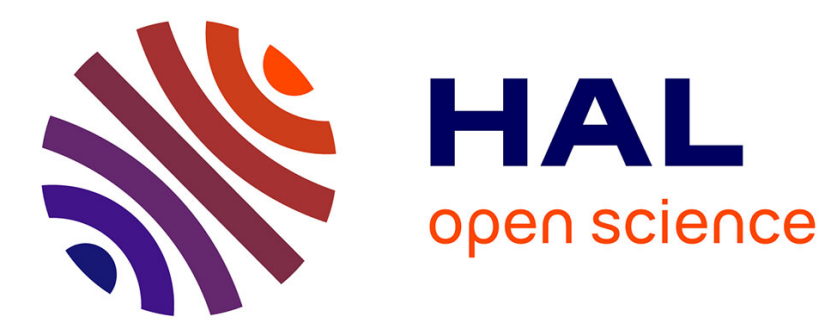

\title{
Crustal exhumation during ongoing compression in the Variscan Maures-Tanneron Massif, France: geological and thermo-mechanical aspects
}

Muriel Gerbault, Julie Schneider, A. Reverso-Peila, Michel Corsini

\section{- To cite this version:}

Muriel Gerbault, Julie Schneider, A. Reverso-Peila, Michel Corsini. Crustal exhumation during ongoing compression in the Variscan Maures-Tanneron Massif, France: geological and thermo-mechanical aspects. Tectonophysics, In press, 10.1016/j.tecto.2016.12.019 . hal-01745102

\section{HAL Id: hal-01745102 \\ https://hal.science/hal-01745102}

Submitted on 30 Mar 2018

HAL is a multi-disciplinary open access archive for the deposit and dissemination of scientific research documents, whether they are published or not. The documents may come from teaching and research institutions in France or abroad, or from public or private research centers.
L'archive ouverte pluridisciplinaire HAL, est destinée au dépôt et à la diffusion de documents scientifiques de niveau recherche, publiés ou non, émanant des établissements d'enseignement et de recherche français ou étrangers, des laboratoires publics ou privés. 


\section{Accepted Manuscript}

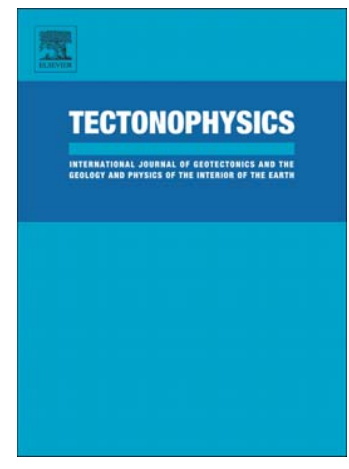

Crustal exhumation during ongoing compression in the Variscan MauresTanneron Massif, France-Geological and thermo-mechanical aspects

Muriel Gerbault, Julie Schneider, A. Reverso-Peila, Michel Corsini

PII: $\quad$ S0040-1951(16)30634-5

DOI: $\quad$ doi: $10.1016 / j . t e c t o .2016 .12 .019$

Reference: $\quad$ TECTO 127362

To appear in: $\quad$ Tectonophysics

Received date: 1 July 2016

Revised date: 13 December 2016

Accepted date: 19 December 2016

Please cite this article as: Gerbault, Muriel, Schneider, Julie, Reverso-Peila, A., Corsini, Michel, Crustal exhumation during ongoing compression in the Variscan Maures-Tanneron Massif, France-Geological and thermo-mechanical aspects, Tectonophysics (2016), doi: 10.1016/j.tecto.2016.12.019

This is a PDF file of an unedited manuscript that has been accepted for publication. As a service to our customers we are providing this early version of the manuscript. The manuscript will undergo copyediting, typesetting, and review of the resulting proof before it is published in its final form. Please note that during the production process errors may be discovered which could affect the content, and all legal disclaimers that apply to the journal pertain. 


\title{
Crustal exhumation during ongoing compression in the Variscan Maures-
}

\section{Tanneron Massif, France -}

\section{Geological and thermo-mechanical aspects}

\author{
Muriel Gerbault ${ }^{1}$, Julie Schneider ${ }^{2}$, A. Reverso-Peila², Michel Corsini²
}

\begin{abstract}
1. GET, Géosciences Environnement Toulouse, CNRS, IRD, Université de Toulouse, Observatoire Midi-Pyrénées, 14 avenue Edouard Belin, 31400 Toulouse, France.

2. Géoazur, UMR 7329, CNRS, IRD, Université de Nice Sophia-Antipolis, Observatoire de la Côte d'Azur, Valbonne, France.
\end{abstract}

21/12/16

\begin{abstract}
The Maures-Tanneron Massif (MTM), together with Corsica and Sardinia, represent the Southeastern branch of the huge European Variscan belt. A continuous evolution from continental collision to exhumation is described from ca. $350 \mathrm{Ma}$ to ca. $320 \mathrm{Ma}$, based on an extended compilation of available geological and geochronogical data. This geological compilation is complemented with thermo-mechanical modelling that tests the conditions under which deep-seated HP units can melt and exhume massively during continued convergence. We simulate in two-dimensions the development of gravitational instabilities in a partially melting crust, depending on rheological layering and heat sources, and accounting for temperature dependent elasto-visco-plastic rheologies. In order to reproduce PT exhumation patterns in the MTM, over the appropriate time-scale (>20 My) and spatial extent $(>100 \mathrm{~km})$, a best fit was obtained with a convergence rate of $0.5 \mathrm{~cm} / \mathrm{yr}$ and moderate diffusive surface processes. The contribution of radiogenic heating in the pre-stacked felsic crustal units is crucial. A lateral alternation with mafic units is also required in order to prevent lateral spreading of the orogen. A low viscosity partially molten crust (102 $\square$ Pa.s, thus rather felsic) accompanies crustal exhumation in a decoupled mode from the deeper mantle. A shallow asthenosphere below the orogen (LAB at $\sim 70 \mathrm{~km}$ depth, eg. shallow slab break-off) produces too warm and sudden exhumation as opposed to a competent mantle lithosphere (120 km depth LAB) that restrains it. The MTM witnesses the typical competition between far-field plate convergence and internal body forces, and our study pleads for a progressive evolution of transpression towards perpendicular extension from ca. $320 \mathrm{Ma}$.
\end{abstract}


Keywords: Variscan orogeny, migmatites, crustal melting, thermomechanical modelling, post-orogenic exhumation, gravitational instability. 


\section{INTRODUCTION}

The factors that drive exhumation of orogenic continental crust have been studied for decades, since England \& Richardson (1977) demonstrated the role of internal heating and surface erosion on the exhumation of high-grade metamorphic rocks. Melting of the thermally re-equilibrating thickened continental crust has been invoked in a number of Precambrian and modern terranes (eg.Thompson \& Connolly, 1995, Huerta et al., 1999). It is now accepted that gravitational instabilities can be responsible for the massive exhumation of granulite and migmatitic complexes, due to temperature increase in multi-layered crustal systems of reduced viscosity and density (e.g. Perchuk et al., 1989; Platt, 1993; Weinberg \& Podladchikov, 1995; Gerya et al., 2000, 2008). Numerical thermo-mechanical modelling reproduces the ascent of low viscosity magmatic material through cold upper crust (Gerya et al., 2008; Faccenda et al., 2008; Lexa et al., 2011), provided the upper crustal strength is sufficiently softened. Yet the capability of buoyant material to pierce through competent crust remains an issue (e.g. Petford \& Clemens, 2000; Handy et al., 2001; Vigneresse et al., 1996; Vigneresse, 2006). Compressional boundary forces are also invoked to sustain vertical channelised exhumation of the lower crust (Thompson et al., 1997, the «tooth-paste » scenario), while efficient surface processes are found to promote ascent along low viscosity narrow channels at the edges of orogenic plateaus, such as along the Himalayas Thrust System (Beaumont et al., 2001 ; Jamieson et al., 2011) and the Variscan Bohemian massif (eg. Schulmann et al., 2009; Maierova et al., 2014). Exhumation of HP crustal rocks along continental collision zones that followed subduction (e.g. Gerya et al., 2008; Yamato et al., 2008; Burov et al., 2012) was explained with a decreasing strength and density of deep seated crustal 'melanges' forced by rigid and dense surrounding material. Slab retreat, break-off (Ueda et al., 2012), or a change in the far-field convergence regime reduce the confinement that retains buoyant melts at depth and thus facilitates their exhumation. Thus tectonic extension (tensile boundary driving forces or slab roll back) is a commonly invoked mechanism to explain lower crust exhumation, as in the Aegean domain (eg. Tirel et al, 2008; Le Pourhiet et al. 2012), the North American Cordillera (Rey et al., 2009), and the Variscan orogeny (eg. Marotta \& Spalla, 2007; Spalla et al., 2014).

The Maures-Tanneron Massif (MTM), Southern France, constitues together with Corsica and Sardinia the Southern European Variscan Belt (SEVB, Corsini \& Rolland, 2009). This segment of the 
European Variscan orogeny has been interpreted as having undergone post-orogenic collapse and lower crust exhumation driven by major trans-current motion and extension. However the MTM portion of the SEVB cannot be easily described by these processes nor those mentioned above (Schneider et al., 2014 and references herein). The late tensile regime of the MTM actually occurred perpendicular to convergence, and exhumation of the partially molten orogenic root actually initiated nearly 50 My earlier (around 340 Ma; Schneider et al., 2014; Oliot et al., 2015). Schneider et al. (2014) recently argued based on structural, petrological and geochronogical data, that diapiric exhumation of the partially molten orogenic root likely began during ongoing convergence at $\sim 345 \mathrm{Ma}$ and continued for about $\sim 20$ My. Such critical transition between (2D) convergence to perpendicular extension remains rarely studied within a coherent framework between geological observation and theoretical numerical modelling. In the present study we consolidate this framework by assessing the conditions for which orogenic exhumation can develop within a 2D plane strain closed system, without any lateral degree of freedom. This study thus provides a basis to be tested in future studies of threedimensional orogenic systems such as the MTM. The paper is therefore organised as follows: in section 2, we complement the geological synthesis of Schneider et al. (2014) with a PTt compilation enriched with published data from Corsica and Sardinia and with recent geochronological data from the MTM (Oliot et al., 2015). Arguments in favour of a compressional setting at the onset of exhumation are strengthened. Section 3 then presents our modelling approach, with detailed justifications of our choices with respect to geological data, in order to seek the conditions under which deep metamorphic units could exhume during plate-boundary convergence. While other modelling studies explore the large-scale sequence of subduction, collision, break-off and extension (eg. Marotta \& Spalla, 2007; Spalla et al., 2014; Gerya et al., 2008), we focus here on crustal-scale processes during the $\sim 20-30$ My time-window after continental collision and before major extension. Section 4 describes our numerical scenario of orogenic crust exhumation and discusses its variability with rheological and thermal parameters. In Section 5 we synthesise these numerical tests with geological data, in order to emphasize the thermo-mechanical evolutionary stage of the MTM from 2D continental collision towards perpendicular extension. We briefly discuss this evolution with respect to other orogens. 


\section{GEOLOGICAL ANALYSIS AND GEODYNAMIC SYNTHESIS IN THE MTM}

The Maures-Tanneron Massif is located in Southern France and belongs to the Crystalline Provence. Its building spanned from Early Devonian to late Carboniferous (Crevola \& Pupin, 1994). It suffered rifting during the Permian, responsible for the separation of the Maures Massif in the South from the Tanneron Massif in the North. It is now widely accepted that the MTM formed a unique domain with Sardinia and Corsica at Variscan times (e.g. Edel et al., 1981, 2014; Elter et al., 2004; Bellot, 2005; Corsini \& Rolland, 2009). Sardinia and Corsica have been disjointed from the MTM during the opening of Mediterranean back-arc basins in the Miocene, undergoing a $55^{\circ}$ anti-clockwise rotation (Gueguen, 1995; Gattacceca et al., 2007). The MTM has roughly a main NS structuration and from NW to SE, its width represents almost $100 \mathrm{~km}$. In the architecture of the SEVB, the MTM constitutes the central segment of the chain, while the foreland is found in South Sardinia and the hinterland in Northern Sardinia and Corsica. The orthogonal section of the whole chain, including Sardinia and Corsica previous to the Miocene rotation, extends over $300 \mathrm{~km}$ on a NW-SE axis (Fig. 1).

\subsection{Architecture of the chain and previously invoked exhumation processes}

The global architecture of the chain presents an asymmetric fan shape (Fig. 1d, Schneider et al., 2014). Relatively to the actual position of the MTM, structures display a NW-SE orientation along which two major tectonic units appear: the External Zone to the West (EZ) and the Internal Zone to the East (IZ, in blue and pink, respectively in Fig. 1). They are separated by the La-GardeFreinet/Cavalaire thrust/detachment plane (Fig. 1).

The External Zone is formed of NW verging folds and nappes of very low-grade metamorphism in the most external part (theses nappes crop out in South-Western Sardinia with a SW vergence in the present day position of Sardinia, e.g. Conti et al., 2001) evolving to SE verging nappes of low, medium to high-grade metamorphism when approaching the Internal Zone (as observed in the MTM and central Sardinia). The NW vergence of the external nappes is related to the first stages SouthEastward underthrusting (defined as D1, overturned folds towards the foreland), while the SE vergence of the most internal nappes is related to the subsequent backthrusting (defined as D2, overturned folds towards the hinterland, and accommodated by several NW dipping shear zones as 
the Bormes Fault or the La-Garde-Freinet/Cavalaire Fault). These thrust planes have been later reactivated as detachments faults during the unroofing and exhumation of the Internal Zone (defined as D3, Fig 2).

The Internal Zone (IZ) consists of high-grade metamorphic rocks that suffered widespread partial melting during the last stages of the orogeny. It is also widely intruded by late-orogenic granitoids plutons. Its main structuration can be depicted as NS oriented dome-like structures $\left(\mathrm{N} 10^{\circ}\right)$ cored by granitoids plutons (i.e. the Hermitan, Rouet and Cannes antiforms in the MTM, Fig. 1, Crevola \& Pupin 1994; Corsini et al., 2010) and separated by NS transcurrent faults (Joyeuse-Grimaud and La Mourre Fault in the MTM). This zone is characterised by transpressive and extrusive NS oriented structures superimposed to D1 and D2 folds and foliation planes. Moreover, relicts of mafic HP rocks are found scattered in this part of the massif. They consist of small eclogites lenses strongly retrogressed in the granulite then amphibolite facies (e.g. Cortesogno et al., 2004; Cruciani et al., 2011). These are interpreted as relicts of subducted oceanic crust and would represent a dismembered suture zone during backthrusting and transpression (Helbing et al., 2006; Schneider et al., 2014).

Exhumation processes invoked for the MTM have actually been mostly of two kinds. The first is related to pure post-collisional gravitational collapse. Invoked arguments are: 1) a progressive change in granitoids chemical signature compatible with a decrease of partial melting depth and therefore decompression (e.g. Ferré \& Leake, 2001; Von Raumer et al., 2003). This argument alone is not sufficient to validate gravitational collapse, since it only indicates crustal upwelling from 340 Ma to 280 Ma (ages of the oldest and youngest granitoids); 2) Recognition in the field of migmatitic domes with local normal shearing on the flanks suggesting core complex structures (e.g. Carmignani et al., 1994; Bellot, 2005). However such dome structures could represent diapiric ascent in a compressive setting with relative collapse of the overriding units, instead of extensional collapse. The main argument against pure post-collisional gravitational collapse is that a clear tensile regime exists at the very end of the orogeny (at ca. $290 \mathrm{Ma}$, e.g. Gattacceca et al., 2004), and that it is oriented orthogonal to the direction of convergence. The second possible exhumation process invokes transpression (e.g. Onézime et al., 1999; Carosi et al., 2005; Rolland et al., 2009, and references therein). Evidences of transpressive shearing along shear planes roughly parallel to the chain structuration (NS) are 
numerous on the field. But again, transcurrent motion started at $320 \mathrm{Ma}$ and can only account for the last stages of exhumation and thinning.

\subsection{A geodynamic conceptual scenario based on petrology and metamorphism}

The scenario that emerged from a synthesis of structural, metamorphic and geochronological data (Schneider et al., 2014), is updated here in order to achieve a critical amount of data in terms of timing, structures, pressure-temperature estimates and evolution of the apparent thermal gradient in the Internal vs. External Zones. The general conceptual model is shown in Fig. 2. Five main orogenic stages have been defined: $\mathrm{D} 0 \mathrm{a}=$ Oceanic subduction, $\mathrm{D} 0 \mathrm{~b}=$ Continental subduction, $\mathrm{D} 1=$ Nappe stacking/Underthrusting, D2 = Backthrusting, D3 = Collapse of the External Zone/Doming and lateral flow of the Internal Zone. Another anorogenic stage D4 is related to Permian Rifting. A description of each stage is detailed in Appendix A. In order to compare data and models in our study, all available metamorphic data in the SEVB have been compiled relatively to their location, protolith, and deformation stage (Fig. 3a). Ages are also displayed in Fig. 3a but do not represent an exhaustive database since the availability of both the PT estimates and the age for a similar sample remains rare. The whole of the geochronoloical database is summarised in Fig. 3b through distribution frequency histograms and Table 1 (data are available in Supp. Material, Appendix A).

Phase D2 lasted about 25 Ma from 345 Ma to 320 Ma (Fig. 3b, Table 1). It started after slab breakoff and the initiation of partial melting in the orogenic root (the earliest peraluminous granitoids, U1', are dated at ca. $345 \mathrm{Ma}$, e.g. Paquette et al., 2003) and ended when the IZ and EZ were fully decoupled and when transcurrent motions started to be recorded at 320 Ma (Carosi et al., 2012; Giacomini et al., 2008; Oliot et al., 2015). The D2 phase follows the nappe-stacking phase D1 and is characterised by progressive backthrusting of tectonic units in the core of the orogenic prism in a direction $\mathrm{N} 140^{\circ}+/-20$ (top to SE sense of shear as shown by the black arrow in Fig. 3 b), and unroofing of the IZ. Two magmatic pulses are recorded during this phase: 1) The U1 magmatism characterised by Vaugnerite and High-Mg/High-K (HMK) signatures with emplacement of synorogenic sheet-like magmatic bodies in conformable continuity with migmatitic foliation. This magmatism is associated to deep-seated sources (mafic granulite from the lower crust and enriched shallow upper mantle, Appendix A). It lasted from 340 to $330 \mathrm{Ma}$ (Paquette et al., 2003; Li et al, 2014; Fig. 3b, Table 1); 2) The U2a' magmatism (330-320 Ma, Table 1, Appendix A) is 
characterised by calc-alkaline plutons of tonalitic to granodioritic composition. They are syn-tectonic and strongly foliated (see for instance the Hermitan granite in the MTM Fig. 1, Rolland et al., 2009; Schneider et al., 2014) and are structurally and thermally concordant with the surrounding rocks in the IZ (thermal equilibrium with the migmatites). In the EZ instead, plutons are intrusive and responsible for contact metamorphism (e.g. Secchi et al., 1991). At the end of D1, the apparent thermal gradient deduced from metamorphic data was between 15 and $18^{\circ} \mathrm{C} / \mathrm{km}$ (Fig. 3). During D2, the gradient rises to $25-27^{\circ} \mathrm{C} / \mathrm{km}$ in the $\mathrm{EZ}$ and up to $40^{\circ} \mathrm{C} / \mathrm{km}$ in the IZ (Fig. 3). D2 is marked by the increase of one order of magnitude of the apparent elevation rate of the thermal gradient from $0.1^{\circ} \mathrm{C} / \mathrm{km} / \mathrm{Ma}$ during $\mathrm{D} 1$ to $0.7-1.1^{\circ} \mathrm{C} / \mathrm{km} / \mathrm{Ma}$ during $\mathrm{D} 3$ in the $\mathrm{IZ}$ and $0.3-0.6^{\circ} \mathrm{C} / \mathrm{km} / \mathrm{Ma}$ in the $\mathrm{EZ}$ (Fig. 3b). This difference in apparent heating rate through time in both zones is a strong argument in favour of the rise and doming of isotherms in the $I Z$ relatively to the $E Z$.

At $320 \mathrm{Ma}$ (phase D3) the IZ and EZ are fully mechanically and thermally decoupled (Appendix A). Thermally, the EZ is believed to be exhumed and equilibrated on a thermal gradient of $25^{\circ} \mathrm{C} / \mathrm{km}$ while the $\mathrm{IZ}$ is still recording an abnormally high thermal gradient up to 50 and $60^{\circ} \mathrm{C} / \mathrm{km}$ (Fig. $3 \mathrm{~b}$ ) and is characterised by high rates of crustal melting (high volume of U2a calc-alkaline magmatism). Mechanically, the EZ collapses relatively to the IZ along reactivated D2 backthrusting planes acting as detachment faults during D3. Meanwhile the partially molten rocks of the IZ are strongly affected by transcurrent motions followed by lateral flow or extrusion in a direction sub-orthogonal to convergence. Giacomini et al. (2008) and Casini et al. (2012) independently propose that this transition occurred around ca. 310-315 Ma with final thinning of the chain. The white arrow showing this direction of extrusion/lateral flow in Fig. $\mathbf{3 b}$ is set at $\mathrm{N} 10^{\circ}$. According to Casini et al., (2012) and Schneider et al. (2014), this stage onsets in a convergent setting (strongly supported by transpressive structures) and our compilation suggests that convergence is still oriented N140 (black arrow Fig. 3b). This is further supported by fold axis orientation in Stephanian basins (Fig. 1) related to active strike-slip shear zones $\left(\mathrm{N} 40-50^{\circ}\right)$. The system cannot be seen as 2D anymore. From $300 \mathrm{Ma}$ (phase D4), NS extension occurs, with emplacement of U3 alkaline plutons in EW tensile fracture orthogonal to the previous lateral flow, suggesting a progressive transition from orogenic thinning to Permian rifting (see Appendix A, Gattacceca et al., 2004; Casini et al., 2015).

\section{THERMO-MECHANICAL MODELLING: METHOD AND ASSUMPTIONS}




\subsection{Spatial and temporal scales considered by the numerical modelling}

The time window to be numerically modelled encompasses phase D2 and spans from $350 \mathrm{Ma}$ ( $t=0$ in the models) to $315 \mathrm{Ma}(\mathrm{t}=35 \mathrm{My}$ in the models, Fig. $\mathbf{3 b}$ and Table $\mathbf{1})$. The field arguments that constrain the models time window are 1) that exhumation initiated during convergence, most probably triggered by slab break-off around 345 Ma (causing U1 HMK magmatism, Casini et al., 2015), and 2) that $2 \mathrm{D}$ compression dominated over transpression until at least $315 \mathrm{Ma}$ (U1 and U2a' granitoids). The first $10 \mathrm{My}$ (from 350 to $340 \mathrm{Ma}$, initiation of D2 = back-thrusting) account for the "orogenic loading" stage and are not analysed in detail (cf. section 3.2 and Appendix B). The next 20 My represent the core of our study, and correspond to the backthrusting period (from 340 to $320 \mathrm{Ma}$ ), when unroofing of the orogenic root is believed to be triggered in a compressive setting and in association with extensive partial melting and emplacement of the first granitoids (U1 and U2a'). From $320 \mathrm{Ma}$, lateral flow is triggered and the two-dimensional approach can no longer be valid. However, we still look at the next $\sim 5 \mathrm{Ma}(35 \mathrm{My}$ in the model $=315 \mathrm{Ma}$ ) in order to visualise the 2D evolution of the chain.

In the MTM, small thermal intrusions and domes obviously witness locally heterogeneous modes of heat transfer. However, despite the scarcity of field sampling, the ensemble of sampled rocks appear to have recorded similar depths and thermal gradients at different moments as they passed through an equivalent vertically flowing section (Fig. 3a). Thus as variable PT paths converge towards similar values (eg. similar thermodynamical state) during progressive exhumation, the Internal Zone behaved like a homogeneous mélange (mush) in terms of bulk mechanical behaviour.

On a small scale, antiform structures (e.g. Hermitan and Rouet) in the IZ are cored by syntectonics granitoids structurally and thermally concordant with the surrounding migmatites (Rolland et al., 2009; Corsini et al., 2010; Schneider et al., 2014). In contrast the EZ records only late HT/LP discordant overprinting (eg. Buscail, 2000; Di Vincenzo et al., 2004), decreasing when moving away from the IZ. On a large scale, global doming of the IZ occurs in association with rising isotherms (Schneider et al., 2014), suggesting a diapiric-like rise of hot material of variable degrees of partial melting that is decoupled from the EZ. 
Exhumation processes at different space and time-scales are not exclusive one from the other (eg. Vigneresse et al., 1996; Vigneresse, 2006). Melt propagates in pulses at $\sim$ metric scale (eg. Rabinowicz \& Toplis, 2009) through a partially molten mush that deforms continuously on the greater crustal scale. On the small scale, magmatic fluids migrate from the middle to upper crust with a viscosity of the order of $10 \square$ Pa.s or less (eg. Thompson \& Connolly, 1995), and at a rate of several meters per year, eg. ca. $10 \mathrm{~km}$ within $10 \mathrm{kyrs}$ (such as the Hermitan and Rouet antiforms). To model such intrusive processes, timescales less than a second are needed (Maxwell relaxation time). Currently numerical models cannot compute both such local fast processes, and the evolution of an orogen several hundred kilometers wide during 20 My (see e.g. Cao et al., 2016, who modelled the cumulated thermal effect of multiple dike intrusions at intermediate time-scales). Furthermore, while on the sample scale melt extraction controls thermodynamic phases changes, on the kilometric scale of numerical thermo-mechanical elements (which covers $10 \square$ measure points of mineral phases), fluid extraction is less evident and may instead rather be part of the bulk behaviour of the partially molten mush.

On the large scale of the MTM, such partially molten mush exhumed within about 20 My. It can be assimilated to a rising Rayleigh-Taylor instability at a Stokes velocity $\left(\mathrm{V} \sim 1 / 4 . \Delta \rho / \eta \cdot \mathrm{gr}^{2}\right)$ that depends on its density contrast $\Delta \rho$ and on the effective viscosity of the crust (eg. Weinberg \& Podaldchikov, 1995; Poliakov et al., 1993; Petford \& Clemens, 2000). As a back-of-the-envelop estimate, for a buoyant instability of radius $r=20 \mathrm{~km}$ and density contrast $\Delta \rho=50-100 \mathrm{~kg} / \mathrm{m}^{3}$ to rise by $30 \mathrm{~km}$ within $10 \mathrm{My}$ (as recorded by geochronological data), the bulk effective viscosity of the medium should be $\eta=$ $10^{1} \square-10^{2} \square$ Pa.s. This effective viscosity corresponds to values extrapolated from experimentally determined power-law creep parameters for unmolten rather felsic crust (Burgmann \& Dresen, 2008), but it is more than 10 orders of magnitude greater than experimentally measured viscosities of molten rocks (eg. Rosenberg \& Handy, 2005). This jump in viscosity represents the jump in scales on which melting processes occur (this is further discussed in section 5). In addition, note that the resulting Stokes velocity of $\sim 3 \mathrm{~cm} / \mathrm{yr}$ estimated above is of the order of continental convergence rates. The question is whether this vertical exhumation is inhibited or not by crustal thickening as convergence continues. Since both processes occur in spatially heterogeneous media, numerical models are needed to study how vertical exhumation can develop within a thickening crust on the orogenic scale. 


\subsection{Model setup}

We use the code Parovoz (Poliakov et al., 1993), based on a dynamic relaxation method (FLAC, Cundall, 1989), to resolve dynamic problems accounting for non-linear constitutive laws. Parovoz explicitly resolves the equation of motion and the heat equation on a Lagrangian grid, with a mixed finite differences formulation. Equations are detailed in Appendix B. The model mesh domain is composed of $600 \times 150$ elements and covers a width of $1000 \mathrm{~km}$ and a depth of $150 \mathrm{~km}$. Elementary resolution is thus about $1.3 \mathrm{~km}$ in width and $1 \mathrm{~km}$ vertically. These dimensions satisfy our aim to focus on processes occurring within the crust rather than on the lithospheric scale. The top surface is automatically meshed so that topography balances isostatically the weight of each vertical column (down to $150 \mathrm{~km}$ depth). Consequently initial topography reaches $\sim 4 \mathrm{~km}$ in the centre of the modelled domain above the $\sim 60 \mathrm{~km}$ thick initial crustal root. The top $80 \mathrm{~km}$ of both lateral borders have a prescribed horizontal velocity (which can be null), while the other boundaries of the domain respond to Archimedes' restoring force (cf. Appendix B).

When defining the initial thermo-mechanical state of our models it is difficult, if not simply wrong, to simulate an active margin that has been undergoing subduction and continental collision for tens of million of years, with a thermally equilibrated and isostatically balanced static system. On the other hand, the pre-Variscan state and the subduction episode in the MTM lack ground data for an appropriate initial setup to be determined for these stages. We have thus chosen to setup our models for an already evolved collisional orogeny and acknowledge its disequilibrium de facto, as in fact other modelling studies do (eg. Yamato et al., 2008; Burov \& Yamato, 2008; Gerbault et al., 2009; Luth et al., 2013 ; Maierova et al., 2014, and references therein). We must then justify the initial shape, temperature and compositions of both the underplated subducting plate and the overriding orogenic prism.

Compositional and Rheological Geometry. Asymmetric rheological layering is defined to represent initially subducting continental crust beneath an orogenic prism set in between two continental lithospheres. Given the geological information for phase D1 preceding D2 (Appendix A), the initial setup considers the following structure (see Tables 2, 3, and Fig. 4a):

- The orogenic prism in the centre is composed of dominantly felsic crust, bounded to the left 
and right by rigid crust. Despite the lack of identification of the easternmost domain on the field, its (high) strength must have been decisive since it impeded lateral spreading of the orogeny (cf. concept of rigid buttress). Therefore the crust to the East was likely made of dominantly mafic and competent material acting as a buttress (dark blue to purple colour in models).

- The core of the orogenic prism is called the Superior Unit (orange prismatic layer in model setup, Fig. 4a) and mimics accumulated nappe stacking at the onset of the model. Lithologies in this prism derive from a mixture of metapelites, metafelsites, metagreywacke and metaigneous rocks from both converging lithospheres. This unit likely behaved with a "damaged" rheology with respect to its surroundings. Preliminary tests show that too rigid (anorthosite) a rheology of this layer prevents any crustal exhumation; therefore this unit is chosen to behave as moderately weak material, eg. by quartzite creep flow properties.

- In this orogenic prism, a thin layer of $5 \mathrm{~km}$ of inclined mafic material (light-blue in model setup) is inserted and embedded in the inherited core of the orogenic prism. It is used as a geometrical marker that idealises a pre-existing suture plane between the overriding and underthrusting tectonic plates.

- The depth of the orogenic prism is defined from the highest PT conditions recorded for continental material in the chain, eg. the felsic HT granulite from South Corsica (Giacomini et al., 2008), eg. $60 \mathrm{~km}$ (Fig. 3a). This is the pre-defined depth of the Superior unit (corner of orange layer in model setup, Fig. 4a), which thus covers upper and lower crustal depths.

- Continental crust from the West underplates the orogenic prism. It is assigned a dipping radius of curvature of $400 \mathrm{~km}$, equivalent to present day collision zones, so that the prism's width extends over about $300 \mathrm{~km}$ at the surface. The Inferior Unit describes both the upper $15 \mathrm{~km}$ of this under-thrusted crust (green layer in the models), and the underlying dipping $20 \mathrm{~km}$ of crust (plain blue in the models). The strength of both layers is tested with various creep parameters ranging from quartzo-diorite to mafic granulite (Tables $\mathbf{3}$ and $\mathbf{4}$, and Appendix B).

- The depth to which the continental crust dips below the Eastern continental lithosphere depends on the depth of previous delamination (or break-off), that occurred soon before the onset of our model and that has set the orogenic wedge out of isostatic and thermal equilibria. 
For the MTM, the lack of field information limits our interest for this process, and synthetic studies of slab break-off, retreat or delamination can be found in Buiter et al., (2002), Andrews \& Billen (2009), Duretz et al. (2011), Duretz \& Gerya (2013). Given these studies, slab retreat, break-off or delamination may occur at variable depths. We choose here to simply define the depth of the thermal lithosphere-asthenosphere boundary $(\mathrm{LAB})$ below the orogenic root with the term « ML » (for Mantle Lamination, equivalent to a local LAB set at $900^{\circ} \mathrm{C}$ ). Two depths are tested, $\mathrm{ML}=70 \mathrm{~km}$ and $\mathrm{ML}=120 \mathrm{~km}$.

Thermal state. The initial thermal state is built with a conventional solution of the diffusive equation for continental lithospheres of ages $400 \mathrm{My}$ and 100 My respectively for the Eastern and Western domains (Burov \& Diament, 1995). This provides for the Eastern and Western lithospheres, an initial gradient of $18-20^{\circ} \mathrm{C} / \mathrm{km}$ and Moho temperatures at $35 \mathrm{~km}$ depth of $450^{\circ} \mathrm{C}$ and $550^{\circ} \mathrm{C}$, respectively. Temperature below the orogenic domain is assumed to have been advected with the dipping subducting lithosphere down to the arbitrarily fixed depth of slab break-off (or delamination) (parameter ML, table 2 and tests in Section 4.3). Radiogenic heating and shear heating are accounted for via the heat equation (Eq. B.2, Appendix B). We test their influences in Section 4.4 below.

Melting assumptions. Partial melting occurs with increasing temperature throughout the crust, and it impacts density and viscosity. A number of numerical thermo-mechanical approaches simulate melting processes by incorporating thermodynamic tables (such as Perplex or Theriak, Yamato et al., 2008), or superimposing fluid flow (Mezri et al., 2015). Here we opted for simpler temperature dependent melting conditions $M(T)$, similarly to Gerya et al., (2008). We also tested the assumptions of Rey et al., (2009, discussed in Appendix B, part 3.5). Since melting is a main step in driving the exhumation of the orogenic crust, governing equations are recalled here (but are also described in Appendix B). The volumetric fraction of melt $M_{\exp }$ is assumed to increase linearly with solidus temperature and is bounded by a maximum amount of fusion $q_{f u s}$ at temperature $T_{f u s}=1200^{\circ} \mathrm{C} . q_{\text {fus }}$ reaches about $80 \%$ for silicates and 30\% for mafic rocks (eg. Ganne et al., 2014 and references therein). Density is then modified as a linear function of $M_{\exp }$ (and the solid and molten reference densities), while viscosity is reduced exponentially: 


$$
\begin{gathered}
M_{\exp }(T)=\left[T-T_{\text {sol }}\right] /\left[T_{\text {fus }}-T_{\text {sol }}\right] \cdot q_{\text {fus }}, \\
\rho(\mathrm{P}, \mathrm{T})=\rho_{\text {solid }}-M \cdot\left(\rho_{\text {solid }}-\rho_{\text {molten }}\right), \\
\eta_{\exp }=5.10^{16} \cdot \exp ^{2.5+(1-M) \cdot\left(\frac{1-M}{M}\right)^{0.48} .}
\end{gathered}
$$

\section{MODELLING RESULTS}

Many parameters interdependently influence the process of continental crust exhumation, and because individual effects have already been extensively studied (eg. Yamato et al., 2008; Faccenda et al., 2008; Gerya et al., 2008; Duretz et al., 2011; Maierova et al., 2014; Duretz \& Gerya, 2013), it would be pointless to present yet another extended catalogue of parametric effects to illustrate standard knowledge:

- convergence speed tends to prevent exhumation because of material burial,

- a generally weak lower crust favours lateral spreading upon orogenic thickening and thus reduces exhumation. A strong lateral crust in turn focuses exhumation of weakened material (by melting or other strain softening),

- rheological weakening results naturally from heating and melting,

- heating occurs under specific time-scales and depth ranges depending on heat sources.

We choose to display here critical factors that appear to have controlled the specific exhumation pattern in the MTM. Our best fitting model M1, is described in Figs. $\mathbf{5}$ and 6, but it should not be regarded as a unique solution. As a preliminary step however, a first model without applied boundary convergence is described (M0) and is then compared to M1 (Section 4.1). Section 4.2 then addresses the competition between buoyancy, boundary conditions and surface processes. The effects of crustal rheologies are illustrated in Section 4.3, whereas contributions from various heat sources are discussed in Section 4.4. Melting conditions and bulk crustal viscosity are summarised in Section 4.5. Other models are displayed in Appendix B (Figs. B.1). A synthesis and comparison with the MTM is presented Section 5.

\subsection{Diapiric exhumation with and without applied convergence}

A preliminary test consists in showing the influence of ongoing convergence, since this was the primary aim of our study. Therefore we first present a model without applied convergence, MO 
(Fig.6a), in order to assess afterwards, the influence of convergence in M1. Case M0 illustrates how the system relaxes only due to the artificial initial input geometries and thermal conditions (Fig. 6a). Within the first $10 \mathrm{My}$, immediate isostatic rebound is accommodated by significant uplift, while initial heat distribution mainly diffuses. If in addition, melting is switched off (not shown here), isostatic relaxation alone uplifts and stabilises the buoyant layers of the orogenic prism (green and orange layers) to about $40 \mathrm{~km}$ depth (2800 kg/m 3 in the crust against $3200 \mathrm{~kg} / \mathrm{m}^{3}$ in the mantle). If melting and internal heating are included, the deepest molten felsic portions of the crust (green layer becomes yellow and then brown above $10 \%$ of melt) develop a gravitational instability that rises through the Superior unit within $20 \mathrm{My}$, forcing it to melt by contact (orange layers become darker and red above $10 \%$ of melt). After ca. $30 \mathrm{My}$, the mafic portion of the Inferior unit also melts and sinks into the mantle (plain blue unit becomes dark green, Fig. 6a). The resulting PTt patterns are rather satisfactory: maximum temperatures approach $900^{\circ} \mathrm{C}$ upon exhumation at $\sim 12 \mathrm{~Kb}$, and geothermal gradients reach $40^{\circ} \mathrm{C} / \mathrm{km}$ at about $6 \mathrm{~Kb}$. The exhumed lower crust extends for about $50 \mathrm{~km}$ and ponds at a relatively constant $15 \mathrm{~km}$ depth, eg. the boundary with competent cold upper crust (Brittle-Ductile Transition BDT). However, negligible deformation affects this upper crust in both the External and Internal domains, and this is a major inconsistency with observations. Some superficial compression develops upon exhumation when the orogenic crust is attached (e.g. mechanically coupled) to a competent lithosphere $(\mathrm{ML}=100 \mathrm{~km}$, Fig. B.1.a), however the width of exhumation is less than $40 \mathrm{~km}$, still inconsistent with observations.

When convergence is applied with $\mathrm{Vb}=0.5 \mathrm{~cm} / \mathrm{yr}$ (model M1, Fig. 5), shortening and thickening produce essentially prograde PT paths during the first $10 \mathrm{My}$ of the model run. This stage could be compared to the end of stage D1 in the MTM, but it also represents, mechanically, the time that the model needs to "build up" a convergent loading state where elastic stress loading occurs up to the yield threshold, so that thickening, flexure, buckling and faulting all develop throughout corresponding domains in the orogen (as has already been described in numerous studies). After $10 \mathrm{My}$, the "suture plane" layer 'retrofolds' (or buckles) from the surface to the base of the orogenic crust, illustrating continuous underplating of the Inferior unit below the External western domain. Meanwhile a gravitational dome starts to form at the base of the orogenic prism, which is still too cold to undergo significant melting (Fig. 5a, panel step 13). 
As convergence continues in M1, this deep central dome continues to rise and pushes aside the overlying layers from below. Both east and westward dipping ductile shear zones accommodate the lateral extrusion of this overlying crust (backthrusting, Fig. 5.b). Strong sub-horizontal shearing structures are expected along the brittle-ductile transition at about 10-15 km depth, where high velocity convecting domains flow outwards below low velocity competent upper crust. Internal heat builds up and is advected upwards contributing to melting of the surrounding crust at higher levels (red layers, Fig. 5a). Fragments of eclogitic and mantellic material are dragged upward within the rising buoyant dome, and the base of the felsic crust shifts upward (boundary between brown and yellow layers with light and dark blue layers), towards $\sim 45 \mathrm{~km}$ depth. Denser crustal domains in turn bury and delaminate (not detected in model figure but correspond to the dark green layers in M0 displayed Fig. 6a). The strength of the lateral surrounding crust and mantle control the way in which deformation remains inside the central domain, inhibiting lateral spreading. Minor amounts of crust actually spread laterally westward.

After $20 \mathrm{My}$, the gravitational dome continues to rise and advects heat, and the apparent geothermal gradient can exceed $30^{\circ} \mathrm{C} / \mathrm{km}$. The borders and base of the dome concentrate maximum vertical velocities as opposed to the relatively passive external domain of the prism to the West. Hottest temperatures $\left(>800^{\circ} \mathrm{C}\right)$ are actually achieved by material that was originally at about $30 \mathrm{~km}$ depth to the East in the Inferior unit, and that was progressively dragged down to about $50 \mathrm{~km}$ within 10 My (plain circle markers in PTt path and panel step 13, Fig. 5a). In contrast the material that first exhumed from the base of the prism (brown layer rising at step 13, Fig. 5a), does not record such high temperatures $\left(<800^{\circ} \mathrm{C}\right)$. The lower crustal material coming from the sides feeds from below the rising domes, with a convective vigour that is illustrated by the mixing of layers of different colours. This mush is composed of rocks with different degrees of partial melting from both the Inferior and Superior units. This partially molten domain extends for nearly $100 \mathrm{~km}$ in width at about $15 \mathrm{~km}$ depth, adopting the shape of an inclined mushroom to the East. The whole vertical column occupied by this migmatitic dome behaves mechanically weak.

Modelled PTt patterns are displayed Fig.5a. A first series of markers from the deepest and warmest units located along a gradient of $15^{\circ} \mathrm{C} / \mathrm{km}$ before $10 \mathrm{My}$ evolve to shallow depths $(10-20 \mathrm{~km})$ along a gradient approaching $40^{\circ} \mathrm{C} / \mathrm{km}$ after 30 My (black circle markers). A second series of markers located at intermediate depths before $10 \mathrm{My}$, exhume along a slightly cooler gradient of $25-30^{\circ} \mathrm{C} / \mathrm{km}$ 
after 20 My. Central areas initially located at different depths exhume to the same level depth and their PTt paths converge, consistent with data (Fig.3a, Schneider et al., 2014).

The velocity at which modelled isotherms are uplifted in the internal zone (IZ) during exhumation (Fig. 5c), compare well with field estimates (Fig. 3b), with increasing values of $1-2^{\circ} \mathrm{C} / \mathrm{km} / \mathrm{Ma}$ during the main exhumation process. Gradients progressively diminish from the centre to the west in the EZ, with gradients spanning $0.1-0.5^{\circ} \mathrm{C} / \mathrm{km} / \mathrm{Ma}$ (a more precise comparison is hindered by the lack of precise quantitative data).

\subsection{Buoyancy, far-field convergence and surface processes}

The competition between internal body forces and far-field tectonics in continental orogens is of prime importance. How can lower crustal exhumation occur concomitantly with convergence? From the above description of model M0 with no convergence (Fig. 6a), the development of gravitational instabilities fits the PTt data, provided sufficient heating allows for melting to occur. However, exhumed material affects a relatively narrow width $(<50 \mathrm{~km}$, eg. further referred to as the width of exhumation) and remains stuck at middle crustal depths (more than in M1). Thus the field observation of massive exhumation to upper crustal levels requires to invoke additional driving forces.

When applying a greater convergence rate (1 cm/yr, M5 Fig.7a, and M32 B1.c), the orogenic domain behaves in a globally stiffer way, and the gravitational instabilities are reduced in favour of either lateral spreading (M5), or crustal thickening (M32). Some exhumation still occurs if the lower crust is entirely felsic and undergoes significant internal heating (M5), but otherwise the orogenic topography exceeds $8 \mathrm{~km}$ height, boundary forces reach $1.510^{13} \mathrm{~N} . \mathrm{m}$ (M32), both of which tend to exceed Earth's standards.

Surface processes are known to participate in crustal exhumation. Upon imposing asymmetric surface processes in our models, so that the Eastern side of the orogen erodes and sediments much faster than the Western side, exhumation is enhanced in the East, through a narrow channel of about $20 \mathrm{~km}$ in width (Fig. 6d, M4). The modelled geometry is then very similar to the results displayed by Maierova et al., (2014) for the Bohemian massif, particularly to the West Sudete system characterised by an orogenic wedge with crustal-scale folding and a mantled gneiss dome structure (Chopin et al., 
2012). However for the SEVB, the field observation of migmatitic domains extending over an area much larger than $100 \mathrm{~km}^{2}$ argues against channelisation and thus against a significant influence of asymmetric surface processes.

In the reference model, we assumed an initial orogenic prism extending down to $60 \mathrm{~km}$ depth. If this prism is set to only $40 \mathrm{~km}$ depth (+5 $\mathrm{km}$ of thickness with respect to the reference Moho depth, not shown here), the first stage of crustal thickening is longer, and thickening occurs down to about $60 \mathrm{~km}$ depth (again), prior to the development of gravitational instabilities. Subsequent exhumation then occurs along patterns similar to those of model M1 but delayed in time. If in contrast the orogenic prism is initially defined $70 \mathrm{~km}$ thick, then topography exceeds $8 \mathrm{~km}$ and exhumation occurs within the first 5 My because of enormous buoyancy forces, which is unrealistic. Thus the assumption of a 60 $\mathrm{km}$ deep prism appears to correctly simulate the end of stage D1. This also indicates that melting and exhumation occur only in long-lived orogens that acquire sufficient crustal thickening.

\subsection{Crustal Rheology controls vertical exhumation vs. lateral spreading}

The rheology of the crust controls the relative proportion of vertical thickening and lateral flow during continental orogeny, as shown by numerical and analogue experiments (Bird, 1991; Beaumont et al., 2001; Vanderhaeghe et al., 2003; Sokoutis et al., 2005; Gerbault \& Willingshoffer, 2004; Cagnard et al., 2006; Rosenberg et al., 2007; Yamato et al. 2008; Gapais et al., 2009 ; Luth et al., 2014).

Upon investigating the behaviour of the Internal and Superior units in our models with several creep-law properties ( $A, n, Q$ extrapolated from rock experiments, eg. Burgmann \& Dresen, 2008), we first found that we could not produce lower crust exhumation unless the Superior unit behaved as weakly as quartzodiorite (or softer, Table 3). An alternative is to assume some kind of softening that would mimic progressive mechanical damage (eg. Weinberg \& Podladchikov, 1995; Gerya et al., 2008; Ganne et al., 2014). We did not choose this option for any of our modelled rheological layers, and this calls for additional empirical tests on possible weakening rates (eg. see previous citations or discussion in Brune et al., 2014). In our opinion: 1) too little data constrain such tests, and 2) complementary strengthening mechanisms (healing) would also have to be included (in order to 
model the behaviour of rocks once exhumed and cooled, and match the integrated plate strength with respect to Earth's tectonic evolution, eg. Bercovici \& Ricard, 2012). Consequently, in order to identify which rheological distribution best fits the MTM, we are left with four possible mechanical crustal configurations:

a) Both lateral crusts left (East) and right (West) of the orogen are dominantly mafic. In this case, radiogenic heating is minimal, melting conditions are delayed, viscosity and density both remain high so that isostatic disequilibrium only produces exhumation over a narrow domain $(<20 \mathrm{~km})$, and rocks remain stuck below $25 \mathrm{~km}$ depth. Final crustal thickness and topography exceed Earth's standards (70 km and $8 \mathrm{~km}$ respectively). One understands that plate deformation and failure would then rather jump out further away to weaker lithospheric domains (and into the third dimension if necessary).

b) Both lateral crusts left (West) and right (East) are dominantly felsic. In this case partially molten material appears widespread, and forms a mechanically weak melange together with already low viscosity un-molten material, that spreads out laterally, relaxing the pressure gradients in the entire orogen (not shown). This reduces the vigour of gravitational instabilities and the PTt paths record low grade metamorphism (P reduces by $1 \mathrm{~Kb}$ and $\mathrm{T}$ reduces by $100^{\circ} \mathrm{C}$ ). Exhumation is thus very limited if not inhibited.

c) Felsic units to the East underplate mafic units to the West. This configuration would make the Easstern domain mechanically stronger (Fig. B.1.h), which is inconsistent with observations of East dipping nappe-stacking structures (cf. Section 2).

d) Superior and Inferior units to the West are dominantly felsic and underthrust a dominantly mafic lower crust to the East. This configuration appears as the only one logically left, and was assumed in our models. However several representative compositions still had to be tested for the Western Inferior units. We display here 2 of our tested compositions, Fig. 6a (M5) and 6d (M8) (cf. Table 4). Too strong subducting units (green and medium blue layers in the initial setup model) allow for exhumation, but the partially molten layers remain capped under too rigid layers (yellow "mushroom cap" of partially molten Inferior unit, model case Fig. 7d). In contrast, a too weak lower crust facilitates mixing and enhances lateral spreading below the $E Z$, at the expense of vertical exhumation (Fig.7a, 7c).

\subsection{Thermal effects: radiogenic, shear and mantle heating sources}


Upon studying now the effect of temperature on exhumation, a first test was made with a $60 \mathrm{~km}$ thick orogenic crust whose basal temperature was set at $900^{\circ} \mathrm{C}$ at the onset of the model. This "warm" setup triggers immediate massive melting and exhumation within less than $10 \mathrm{My}$. This result is not consistent with geochronological constraints from the MTM area. Therefore one understands that heat somehow accumulated slowly over $\sim 20 \mathrm{My}$ in order to trigger progressive melting and exhumation as indicated by data (Fig. 3 and Table 1).

Radiogenic heating in the crust has long been recognised to be of primary importance for crustal melting and exhumation (Thompson \& Connolly, 1995; Huerta et al., 1999; Gerya et al., 2000; 2008). Our models show general agreement with these studies, with thermal incubation of a $60 \mathrm{~km}$ thick crust producing about $25 \%$ of partial melting and an increase in temperature of about $300^{\circ} \mathrm{C}$ within 20 My.

At the onset of model $\mathrm{M} 1$, surface heat flow is close to $57 \mathrm{~mW} / \mathrm{m}^{2}$ in the Western subducting plate, decreases to $46 \mathrm{~mW} / \mathrm{m}^{2}$ in the thickened cold orogenic prism, and attains $52 \mathrm{~mW} / \mathrm{m}^{2}$ in the Eastern overriding plate (close to standard continental values eg. Goutorbe et al., 2011; Mareschal \& Jaupart, 2014). In assuming a constant radiogenic heat source $H_{l}=8 \cdot 10^{-10} \mathrm{~W} / \mathrm{kg}$ in the orogenic crust (height h), the maximum contribution of the crustal column reaches $\rho \cdot H_{1} \cdot h=157 \mathrm{~mW} / \mathrm{m}^{2}$ $\left(\rho \cdot H_{1} \approx 2.3 \mu \mathrm{W} / \mathrm{m}^{3}\right)$. Within the 30 My of the model run, rising temperatures in the orogenic prism produce a surface heat flow ranging from ca. 75 to $100 \mathrm{~mW} / \mathrm{m}^{2}$ from the $E Z$ towards the $I Z$. These values are consistent with measurements in present day active orogens such as the Altiplano or the Himalayas (surface heat flows $\sim 100-200 \mathrm{~mW} / \mathrm{m}^{2}$, Huerta et al., 1999; Goutorbe et al., 2011). We tested the following additional model cases:

- If the radiogenic heat source in pre-stacked units is increased to $\mathrm{H}_{1}=10^{-9} \mathrm{~W} / \mathrm{kg}$ (model M6, Fig. 7b), then a significant width of the exhuming lower crust achieves $1000^{\circ} \mathrm{C}$ after $20 \mathrm{My}$. Surface heat flow reaches $95-110 \mathrm{~mW} / \mathrm{m}^{2}$ over a $>140 \mathrm{~km}$ wide $\mathrm{IZ}$, which is still acceptable compared to present day measurements. The width and extent of high degrees molten crust slightly exceeds what is observed in the SEVB.

- If in contrast radiogenic heat in the orogenic prism is lowered to $H_{1}=5.10^{-10} \mathrm{~W} / \mathrm{kg}$ then exhumation occurs with temperatures only very locally reaching $700^{\circ} \mathrm{C}$, which is insufficient compared to observations. Zero radiogenic heating drastically prevents lower crustal melting and exhumation (Appendix Fig. B.1.e). 
Our results corroborate previous studies that found that a significant contribution of radiogenic heating in orogenic prisms best explains the measured PTt patterns of a number of exhumed crustal roots (eg. Huerta et al., 1999; Faccenda et al., 2008).

The assumption of accumulated shear heating along the plate interface between the Inferior and Superior units was also tested by applying additional heating over a width of 5 to $10 \mathrm{~km}$ along this boundary, associated to a shear stress of 5 to $10 \mathrm{MPa}$ (eg. Turcotte \& Schubert, 2002). When accounting for shear heating alone (not shown here), diapiric domes exhume through the upper crust over a narrow width of less than $30 \mathrm{~km}$ within $10 \mathrm{My}$, and temperature increases to $900^{\circ} \mathrm{C}$ only very locally. The rest of the crustal root has no time to heat prior to exhumation, thus global PTt cooling paths evolve to cooler geothermal gradients. This result indicates that shear heating may have indeed played a role locally in producing high-grade granulites such as those reported in Corsica (see Section 2.2). On the other hand, the fact that only a single data point reports such high PT is consistent with a relatively localised effect of shear heating in space. We doubt that shear heating could be significant over a broader area (eg. Duprat-Oualid et al., 2012).

When investigating the influence of the mantle in heating the orogen from below, we expect that a model with too deep a $L A B$ depth below the orogenic root will refrain isostatic rebound during melting, whereas a shallow LAB will add sudden excess heat and speed up lower crust exhumation. Our models with a shallow $(\mathrm{ML}=70 \mathrm{~km})$ and deep $(\mathrm{ML}=120 \mathrm{~km})$ thermal mantle (models $\mathrm{M} 2-3-5$, Table 4, Fig. 6, Fig B.1) confirm these predictions. They indicate that within this depth range, both crustal composition and internal heating remain first order conditions for exhumation in the SEVB context. If the orogenic lower crust is rather mafic and behaves strong, it remains mechanically 'attached' to a competent mantle lithosphere, and massive exhumation is prevented. If instead the lower crust is felsic, then mechanical decoupling occurs whatever the strength (and thickness) of the underlying mantle (see also Yamato et al., 2008 for crust-mantle lithosphere coupling).

\subsection{Viscosity of the crust and melting conditions}

When the bulk viscosity of the lower crust increases, its ability to flow diminishes, thus delaying if not preventing, the development of gravitational instabilities. 
- When setting a minimum viscosity of $\mu_{\min }=10^{19} \mathrm{~Pa}$.s for crustal layers (instead of $10^{2} \square$ Pa.s. in M1, Figs. B1.f,g), exhumation occurs within 10 My. But only the initially deepest thickened crust exhumes fast, and convective cycles appear on the PTt record. The resulting dome is either too narrow (<60 km wide) compared to observations or displays too sharp PTt decompression paths.

- If instead crustal viscosity is prescribed to remain above 1021 Pa.s (not shown), then instabilities still develop over correct timescales, but advective processes are slowed down, maximum temperatures are reduced, and PTt patterns are too cold.

- When considering heterogeneous viscosities (Fig. 7c), with $2.10^{1} \square$ Pa.s for partial melts and bounded above $10^{2} \square$ Pa.s for un-molten crust, then several molten domes form and detach progressively from the core horizon of the orogenic root, rising individually through the middle-crust. This is consistent with structures found in the MTM.

It would be useful to complement field data with measurements of the characteristic width of migmatitic domes, which would help constrain the bulk viscosity with which they formed. This set of tests also raises the limitations of numerical models in capturing the development of small size migmatitic domes. Partially molten crust likely exhumes simultaneously on small scales with highly contrasted viscosities depending on compositional heterogeneities (see discussion Section 3.2).

In model M1 we have chosen melting temperatures for felsic Units similar to other studies (Thompson \& Connolly, 1995; Ganne et al., 2014; Cruciani et al., 2008). We tested higher melting thresholds Tsol $=740^{\circ} \mathrm{C}$ (Fig. B.1.d), corresponding to reactions in absence of free water. Then the resulting buoyancy-driven exhumation requires greater heat accumulation, and is delayed by several My. The overall geometry of the domes adopts a more circular shape (diffusive effect of heat on deformation via low viscosity flow), compared to the reference model. We envision that local pockets of greater amounts of melt could also form in areas of lower water content, at a delayed timing with respect to the main exhumation stage.

A model in which the density of molten material was decreased (down to $2650 \mathrm{~kg} / \mathrm{m}^{3}$ instead of $2700 \mathrm{~kg} / \mathrm{m}^{3}$ in the reference case) obviously facilitates exhumation. But once again, too rapid exhumation prevents the development of sufficient temperature and reduces the timing, compared to petrological and geochronological data. Models testing variable melting laws $(M(T))$ and viscosity dependency on melt $\mu(M)$ (eqs. B.5 and B.6, Fig. 4b, Appendix B) develop significant differences 
whether a linear or an exponential decrease in viscosity is assumed. Melting and exhumation are significantly reduced when assuming linear dependency (not shown), and thus we favour an exponential dependency (Eq. B.5, Gerya et al., 2008). A number of other parametric combinations were explored and many were not, however the usefulness of such tests for the MTM context remains speculative until more precise petrological and geochronogical information is gathered.

\section{COMPARISON BETWEEN FIELD DATA AND MODELS, DISCUSSION}

\subsection{Controls on exhumation in the MTM, part of the SEVB}

To summarise, the comparison of our thermo-mechanical models with the structures and petrology of the Maures-Tanneron-Massif, part of the SEVB (with Corsica and Sardinia) during the 350-320 Ma time window, tells us that lower crust exhumation in the MTM likely occurred according to the following specific conditions, listed according to domain boundary effects (i-iii), thermal conditions (iii-vi), crustal melting (vii-viii) and composition issues (ix-ix):

i. Boundary driving forces were moderate during ca. $20 \mathrm{Ma}$, with a standard collision rate of ca. $0.5 \mathrm{~cm} / \mathrm{yr}$ over this period that is consistent with present-day rates in continental orogens. Our model displays compressive structures (folds and faults) and localised westward downdipping shear zones at the EZ-IZ transition Upper Crust. They accommodate exhumation of the IZ dome from below, and are consistent with Schneider et al. (2014)'s observations. If exhumation occurred after cessation of "EW" convergence in the MTM, then another source of compression should be invoked to explain the observations. This is delicate given the evidence in the MTM that extension developed perpendicular to the direction of convergence. Note that our proposition does not rule out the progressive rise of such tensile boundary conditions.

ii. Surface processes influenced the geometry of exhumation, yet they unlikely were preponderant in the MTM and the entire SEVB, or else they would have produced narrower exhumation extent than observed. Furthermore exhumation domains are not systematically associated with major normal nor thrust shear zones, to the difference of other orogenic belts where this influence was revealed (eg. Beaumont et al., 2001; Godin et al., 2006; Mairova et al., 2014).

iii. We could not sharply decipher whether a shallow $(70 \mathrm{~km})$ or deep $(120 \mathrm{~km})$ slab break-off triggered exhumation in the MTM around 350 My. Shallow mantle temperatures allow to reduce the 
contribution of internal heating. Yet a too shallow mantle generates too abrupt isostatic rebound, too rapid heat transfer (large areas at $\mathrm{T}>900^{\circ} \mathrm{C}$ ) and thus too rapid exhumation (in less than $10 \mathrm{My}$ ). However, it is worth noting that slab break-off or delamination may have occurred actually even deeper than $120 \mathrm{~km}$, provided that the lower crust was weak. A relatively low viscosity (eg. dominantly felsic) lower crust in the MTM allows for mechanical decoupling between the shallow levels from which buoyant material exhumes upwards, and the deeper levels in which heavier residual material sinks (Duretz \& Gerya, 2013).

iv. The thermal state of the orogenic lower crust was not 'initially' hot, but it rather accumulated internal heat during at least $20 \mathrm{Ma}$. We advocate for a significant influence of radiogenic heating (responsible for exhumation over a width of ca. $100 \mathrm{~km}$ ) and a minor influence of shear heating (which could still trigger locally high peak temperatures $>900^{\circ} \mathrm{C}$, comparable to the Corsica felsic granulite single data-point). Our assumptions of radiogenic heating in the orogenic crust generate a surface heat flow of the order of $100 \mathrm{~mW} / \mathrm{m}^{2}$ that is consistent with measurements in present day large orogenies such as the Altiplano and the Himalayas (Goutorbe et al., 2011, and references therein), and with other equivalent modelling studies (eg. Faccenda et al., 2008).

v. Radiogenic heating of stacked middle crust advocates for a dominantly felsic crustal root (Mareschal \& Jaupart, 2013). Yet a highly felsic composition behaves too weak and favours lateral spreading of the crustal root at the expense of vertical exhumation (eg. Gerbault \& Willingshoffer, 2004). A mafic crust in contrast, generates less internal heating, and leads to unrealistic boundary forces and mountain height compared to Earth standards.

vi. The vaugnerite and high-Mg high- $\mathrm{K}$ chemical signature of U1 magmatism at ca. 340-330 Ma (Fig. 3b) in the Corsica terranes (there is no formal evidence for U1 magmatism in the MTM), indicates that internal heat may alternatively have been brought by repeated local mantle intrusions in the form of pulses during more than $10 \mathrm{My}$. This could have progressively increased the mean lower crust temperature. This process was invoked by Vorhies \& Ague (2011) to explain Barrovian metamorphism along the Highland Boundary fault zone in Scotland. Since we are not able to tackle such processes with our kilometric resolution model, we can only recognise that this is an alternative mode of progressive heating to that of radiogenic decay in the lower crust. Yet, from a mathematical point of view this 'internal' source can still be modelled in a similar way within the heat equation, and thus it does not rule out our results. 
vii. Melting temperatures directly control the time required to accumulate heat prior to modifying the properties of melting material. Since the MTM migmatites indicate rather hydrated melting conditions, we favour relatively moderate melting temperatures. However it is possible that locally, dryer domains melted later under greater heat, thus leading to several episodes (or pulses) of exhumation over $20 \mathrm{My}$.

viii. The bulk viscosity of partially molten crust drastically decreases at less then $10 \%$ melt threshold (Rosenberg \& Handy, 2005). We found here that a moderate bulk viscosity (10² $\square \mathrm{Pa} . \mathrm{s})$ best reproduces the behaviour of the partially molten MTM crust at large scale, while a lower viscosity (101 $\square$ Pa.s) generates too rapid exhumation and limits heat accumulation. This shows how the partially molten mush behaves metastable at critical melt connectivity, at an effective viscosity of at least 10 orders of magnitude greater than the melt. The low viscosity melt pockets are thus temporally buffered throughout the mush, and then extracted from this mush above critical thresholds (Khodakovskii et al., 1995; Rabinowicz \& Toplis, 2009), producing the smaller intrusive structures observed on field (eg. dikes and plutons). Further field studies should estimate pluton and migmatite sizes, to correlate with improved high resolution seismic tomographies of orogenic and magmatic systems (eg. Koulakov et al., 2013). A better physical link is required to account for the scales of melt extraction and propagation from its partially molten mush matrix (eg. multiphase viscosity, Huber et al., 2011). This should help explain the variety of intrusive structures observed throughout the MTM (and SEVB).

ix. Lardeaux et al. (2014) reviewed the orogenic evolution of the French Massif Central, the Vosges and the Bohemian Variscan massifs, and mentioned how the presence and location of mafic vs. felsic units forming the lower to middle crust actually controlled the geometrical evolution of each massif in a different manner. Basically, felsic lower crustal units favour both the accumulation of internal heating and the production of buoyant melts with respect to mafic units, the latter in contrast acting as a rigid buttress that guides vertical exhumation. Thus the presence of both rheologies on either side of an orogen promotes the exhumation of its roots, in agreement with other modelling studies (eg. Yamato et al., 2008, for the Alpine orogeny; Jamieson et al., 2011). In fact it seems that the heterogeneous three-dimensional layering in felsic and mafic units throughout the Variscan orogeny controlled its geometrical evolution (eg. Weil et al., 2013; Lardeaux et al., 2014; Schulmann et al., 2014), and allowed different domains to accommodate differently the huge internal gravitational 
forces built in its core. At some point, most compliant layers located at different depths in the lateral neighbourhood of the orogenic core perceived and transferred stress from the inner to the outer shallower domains (Bird, 1991; Gerbault \& Willingshoffer, 2004). The orogenic system seeking to minimize its potential energy (eg. Rosenberg et al., 2007; Schmalholz et al., 2014) spread out towards these more compliant felsic domains, initiating strike-slip motion and heterogeneous structures that drove, ultimately, to the thinning of the orogen and locally to Permian rifting (eg. Gattacceca et al., 2004; Casini et al., 2015).

\subsection{Comparison with syn-compressional exhumation in other orogenic belts}

Amongst the European Variscan Massifs, the Bohemian massif might be the one that resembles most the SEVB. The Bohemian massif (BM, Fig. 1 inlet) covers a much wider area than the SEVB system studied here, and displays a number of internal variations itself: 1) the central part of the BM, eg. the Moldanubian Internal zone, recorded vertical mass transfers associated to channelised flow of the orogenic lower crust over lateral distances of about $200 \mathrm{~km}$, essentially driven by buoyancy and surface processes (Schulmann et al., 2008; Jamieson et al., 2011; Maierova et al., 2014). 2) In contrast, the northern part of the BM, eg. the West Sudete System, is characterised by crustal-scale folding intruded by gneiss dome structures that assisted the uplift and exhumation of the lower crust (Chopin et al., 2012). This latter system displays similar ages and structures as those reported here during the D2 phase of the SEVB. However, the exhumation of lower crustal levels lasted in total $50 \mathrm{My}$ in the SEVB, much longer than the $15 \mathrm{My}$ reported for the BM. The apparent difference observed between the Central Moldanubian and Sudete parts of the BM could be explained by their relative position within the Variscan orogenic belt and their different thermal state. Specifically, assuming a similar convergence rate, the smaller size of the thickened Sudete domain would have led to less thermal maturation, while a more felsic composition of the Central domain would have produced greater radiogenic heat; both conditions would have favoured a hotter thermal state in the Central domain (Maierova et al. 2014) than in the northern edge (West Sudete) of the BM. In comparing the SEVB with the Sudete domain of the BM, the former exhibits a greater spatial distribution of partial melting and a less evident contribution from the mantle, indicating that differences in rheological strength and boundary conditions also played an important role in driving their tectonic evolution (eg. Lardeaux et al., 2014). A full understanding of the interactions between 
inherited layering of the converging lithospheres, their variation in strength upon orogeny, and then the dynamics of the three-dimensional boundary conditions, requires to develop larger scale 3D models of the entire Variscan Europe. This will enlighten the dynamics between areas where "space was made" as opposed to areas where space was consumed, and how each orogenic massif first behaved independently up to its own "critical" point of expansion, and how then each massif evolved constrained by the others on a large scale.

The Variscan belt is sometimes compared in size to the ongoing India-Asia collisional orogeny. However distinct exhumation patterns are reported in different domains throughout both orogenies, reflecting a variety of tectonic processes (eg. Gapais et al., 2009 ; Lardeaux et al., 2014 ; Searle, 2015). Throughout the India-Asia collision zone, accommodation of present day shortening remains debated from the upper crust down into the upper mantle (eg. Replumaz et al., 2014; Searle, 2015). Seismic tomography and geochemistry on volcanic rocks throughout the little deformed Tibetan plateau indicate that hot mantle was progressively shunted northward by the underthrusting of Indian lithospheric mantle from the south from $50 \mathrm{Ma}$ to c. $13 \mathrm{Ma}$ (see review and references in Searle, 2015). The identification of a dry granulite lower crust supports the presence of a competent underthrusted Indian lithosphere and limited crustal flow. However temperatures of $900-1000^{\circ} \mathrm{C}$ at $60-80 \mathrm{~km}$ depth since 30 Ma were also reported, indicating that melting has been occurring since then. Geophysical and geological data reveal the presence of weak zones at different depths spanning from the upper crust to the lower crust in different portions of the collision zone, thus indicating some form of lateral flow (Klemperer, 2006).

Beneath the Himalaya and southern margin of Tibet, geophysical data image a partially molten mid-crustal layer between $\sim 15-30 \mathrm{~km}$ depth that can be traced southwards in alignment with the Greater Himalaya Sequence (GHS, Searle, 2015, and references therein). Composed of sillimanite-K-feldspar gneisses, migmatites and leucogranites of Indian crustal origin, the GHS exhumed to the surface in between the two low-angle Main Central Thrust and the South Tibetan Detachment, structurally distant by about 10-20 $\mathrm{km}$. The GHS is interpreted as a partially molten mid-crustal layer flowing southward over 
$\sim 100 \mathrm{~km}$ relative to the upper and lower crust, at c. 23-15 $\mathrm{Ma}$, and driven from topography overburden, underthrusting and up to $20-25 \mathrm{~km}$ of erosion since the Miocene (eg. Godin et al., 2006; Parsons et al., 2011). The GHS also intruded into host sillimanite gneisses, and it displays along its strike variations in exhumation rates that are attributed to variations in viscosity (Parsons et al., 2011).

Elsewhere throughout the India-Asia collision zone, most migmatites and granites are exposed along strike-slip shear zones. For instance, the Karakoram metamorphic sequence has undergone great amounts of crustal thickening $(70-90 \mathrm{~km})$, leading to partial melting, and its exhumation would have been led by transpression followed by debated amounts of strike-slip motion (eg. Searle, 2015). The spatial association between high-grade metamorphic rocks and crustal-scale shear zones is still debated, although it is noted along many orogenic belts spanning from the Proterozoic to present day (eg. Weinberg \& Podladchikov, 1995; Petford \& Clemens, 2000; Vigneresse, 2006 ; Gapais et al., 2009; Jamieson et al., 2011; Searle, 2011; Ganne et al. 2014 ; and references therein).

Syn-compressional exhumation of lower crustal rocks observed throughout the modern India-Asia collision zone is in our view limited by much too rapid convergence rates (about $4 \mathrm{~cm} / \mathrm{yr}$ ). In this context, where the thickened crust is sufficiently felsic and has reached thermal maturation, lateral flow of partially molten layers remains mostly confined within the middle crust because of overall high strain-rate conditions and competent surroundings. Actually our models with greater convergence rates and lower heat production would be appropriate for an «India-Asia » configuration, and in fact they reproduce confined lateral mid-crustal flow below the orogen. Escapement upwards only occurs where the upper crust is sufficiently weak and erosion rates sufficiently high, to channelise flow of partially molten material along shear zones to the surface, such as the GHS in the Himalayas. Our models with efficient surface processes reproduce channelised exhumation of molten lower crust, and thus approach the conditions identified along the Himalaya GHS (eg. Godin et al., 2006,) and in the Central Bohemian massif (cf. Maierova et al., 2014). We may thus conclude that, all other parameters assumed roughly equal (yet, this was unlikely), surface processes were mild in the SEVB, or else structures would have resembled those of the BM and Himalayas. This would probably explain in the SEVB, (1) the absence of a large sedimentary basin as observed in the West Sudete in the BM, 
and (2) why syn-compressional exhumation lasted much longer than in the BM and the Himalayas.

\section{CONCLUSION}

Our study crossed-referenced geological data and quantitative models to show that the first 20 My of lower crust exhumation in the Variscan Maures-Tanneron Massif can be explained by gravitationally driven vertical flow during ongoing convergence. Gravitational instabilities grew from increasingly buoyant partial melt in thickening lower crust. Partial melting was triggered by the slow accumulation of internal heat, allowing for body forces to progressively exceed the burial force induced by far-field compression. Our numerical models show a generally good agreement with field data concerning:

1) A syn-compressional exhumation timing of $20 \mathrm{My}$ and an exhumation width exceeding $100 \mathrm{~km}$;

2) The individualization of two major zones: an intensively partially molten Internal zone (IZ) in the East of the model and a cooler External zone in the west (EZ). The IZ is characterised by doming isotherms leading to an increase in the apparent thermal gradient from 15 to $30-40^{\circ} \mathrm{C} / \mathrm{km}$ at a rate of $1-2^{\circ} \mathrm{C} / \mathrm{km} / \mathrm{Ma}$;

3) Westward backthrusting of the Upper Crust, with formation of a major west dipping shear zone acting like a detachment plane between the exhuming $I Z$ relatively to the $E Z$ (equivalent to La Garde-Freinet Cavalaire fault zone) ;

4) Mixing of orogenic crustal units and dismemberment of previously continuous stacked orogenic nappes.

Internal heating was confirmed as a major heat source with respect to shear heating and basal heating from the mantle, although a contribution from both these sources is not excluded. This major role of radiogenic heating is consistent with the findings of studies of other exhumed orogenic crusts. An orogenic crust composed of dominantly felsic units against a mafic buttress not only explains the asymmetry and dimensions of exhumation in the MTM, but also appears as the only combination that allows, first to maintain a relatively localised thickened orogenic domain, and second, to drive widespread exhumation of this orogenic crust in a maintained compressional regime. 


\section{ACCEPTED MANUSCRIP}

The present study shows that it is not necessary to cease convergence to trigger exhumation of an orogenic crust, even in the absence of intense surface processes. The MTM area is characteristic for having preserved this progressive transition between East-west thickening and perpendicular NorthSouth opening, later on. The Internal domain where folding and gravitational instabilities developed became mechanically weak on a large enough scale that it could focus subsequent trans-current perpendicular motion. A three-dimensional approach is now required to identify how the trans-current structures were influenced by free borders to the (relative) North and South of the domain, allowing for the return to normal crustal thickness and Permean rifting. In other orogenic belts, this transition can be either aborted or circumvented by other processes, such as channelised exhumation driven by surface processes, greater basal heat, or a reversal of the convergence regime to extension (for instance driven by slab roll back).

\section{Acknowledgements}

The authors thank reviewers S. Brune and P. Maierova, K. Schulmann, guest editor F.O. Marques and editor Philippe Agard for constructive comments that improved the manuscript. Feedbacks with JM. Lardeaux, E. Oliot, J. Ganne, M. Rabinowicz, and D. Yuen on early versions greatly helped focusing on relevant issues. Jez Cusworth and J. Gerbault are deeply thanked for helping with english edition. his Clusters Thera (Geoazur, OCA) and Nuwa (LA, OMP) were used for the numerical study. Genia Burov is acknowledged as having shown the way towards the tricky tuning of thermomechanical parameters to model the behaviour of continental lithospheres, seeking to afford sensible physical interpretations of geological and geophysical data. 


\section{REFERENCES}

Andrews, E. R., Billen, M. I., 2009. Rheologic controls on the dynamics of slab detachment. Tectonophysics, 464(1): 60-69.

Beaumont, C., Jamieson, R.A., Nguyen, M.H., Lee, B., 2001. Himalayan tectonics explained by extrusion of a low-viscosity crustal channel coupled to focused surface denudation. Nature, 414: 738 - 742.

Bellot, J.-P., Bronner, G., Marchand, J., Laverne, C., Triboulet, C., 2002. Thrust and normal faulting in the Western Maures (SE France): evidence for geometric, kinematics and thermobarometry of the Cavalaire shear zone. Géologie de la France, 1: 21-37.

Bellot, J.-P., 2005. The Palaeozoic evolution of the Maures massif (France) and its potential correlation with others areas of the Variscan belt: a review. J. Virtual Explorer, Electronic Edition, 19: 1-24.

Bercovici, D., \& Ricard, Y. (2012). Mechanisms for the generation of plate tectonics by two-phase grain-damage and pinning. Physics of the Earth and Planetary Interiors, 202, 27-55.

Bird, P., 1991. Lateral extrusion of lower crust from under high topography in the isostatic limit. J. Geophys. Res. 96(B6): 10275-10286.

Bittner, D., Schmeling, H. (1995). Numerical modelling of melting processes and induced diapirism in the lower crust. Geophysical Journal International, 123(1), 59-70.

Bonin, B., Brändlein, P., Bussy, F.,et al., 1993. Late Variscan magmatic evolution of the Alpine basement. In Pre-Mesozoic geology in the Alps (pp. 171-201). Springer Berlin Heidelberg.

Brune, S., Heine, C., Pérez-Gussinyé, M., Sobolev, S. V. (2014). Rift migration explains continental margin asymmetry and crustal hyper-extension. Nature Communications, 5, 4014, doi:10.1038/ncomms5014.

Buiter, S. J., Govers, R., Wortel, M. J. R., 2002. Two-dimensional simulations of surface deformation caused by slab detachment. Tectonophysics, 354(3): 195-210.

Bürgmann, R., Dresen, G., 2008. Rheology of the lower crust and upper mantle: Evidence from rock mechanics, geodesy, and field observations. Annual Review of Earth and Planetary Sciences, 36(1): 531.

Burov, E. B., Diament, M., 1995. The effective elastic thickness (T e) of continental lithosphere: What does it really mean?. J. Geophys. Res. 100: 3905-3927.

Burov, E., Yamato, P., 2008. Continental plate collision, P-T-t-z conditions and unstable vs. stable plate dynamics: insights from thermo-mechanical modelling. Lithos, 103(1): 178-204.

Burov, E., Francois, T., Yamato, P., Wolf, S., 2012. Mechanisms of continental subduction and exhumation of HP and UHP rocks. Gondwana Research, 25: 464-493.

Buscail, F., 2000. Contribution a la comprehension du probleme geologique et geodynamique du masif des Maures : Le métamorphisme régional modélisé dans le système KFMASH: analyse paragénétique, chémiographie, thermobarométrie, géochronologie Ar / Ar. Ph.D. Thesis Inist 23485255, University Montpellier II, Montpellier, France.

Cagnard, F., Durrieu, N., Gapais, D., Brun, J. P., Ehlers, C., 2006. Crustal thickening and lateral flow during compression of hot lithospheres, with particular reference to Precambrian times. Terra Nova, 18(1): 72-78.

Carmignani, L., Carosi, R., Di Pisa, A., Gattiglio, M., Musumeci, G., Oggiano, G., Carlo Pertusati, P., 1994. The hercynian chain in Sardinia (Italy). Geodinamica Acta, 7(1): 31-47.

31 Gerbault et al., november 2016 
Cao, W., Kaus, B. J., \& Paterson, S. (2016). Intrusion of granitic magma into the continental crust facilitated by magma pulsing and dike $\square$ diapir interactions: Numerical simulations. Tectonics, 35(6), 1575-1594.

Carosi, R., Frassi, C., Iacopini, D., Montomoli, C., 2005. Post collisional transpressive tectonics in northern Sardinia (Italy). J. Virtual Explorer, 19(3): 1-18.

Carosi, R., Montomoli, C., Tiepolo, M., Frassi, C., 2012. Geochronological constraints on post-collisional shear zones in the Variscides of Sardinia (Italy). Terra Nova, 24(1): 42-51.

Casini, L., Cuccuru, S., Maino, M., Oggiano, G., Tiepolo, M., 2012. Emplacement of the Arzachena Pluton (Corsica-Sardinia Batholith) and the geodynamics of incoming Pangaea. Tectonophysics, 544: 31-49.

Casini, L., Cuccuru, S., Puccini, A., Oggiano, G., Rossi, P., 2015. Evolution of the Corsica-Sardinia Batholith and lateorogenic shearing of the Variscides. Tectonophysics, 646: 65-78.

Chopin, F., Schulmann, K., Skrzypek, E., Lehmann, J., Dujardin, J.R., Martelat, J.E., Lexa, O., Corsini, M., Edel, J.B., Štípská, P., Pitra, P., 2012. Crustal influx, indentation, ductile thinning and gravity redistribution in a continental wedge: Building a Moldanubian mantled gneiss dome with underthrust Saxothuringian material (European Variscan belt). Tectonics 31. doi:10.1029/2011TC002951.

Cocherie, A., Rossi, P., Fouillac, A. M., Vidal, P., 1994. Crust and mantle contributions to granite genesis-An example from the Variscan batholith of Corsica, France, studied by trace-element and Nd Sr O-isotope systematics. Chemical Geology, 115(3): 173-211.

Conti, P., Carmignani, L., Funedda, A., 2001. Change of nappe transport direction during the Variscan collisional evolution of central-southern Sardinia (Italy) PAL. Tectonophysics, 332: 255-273.

Corsini, M., Rolland, Y., 2009. Late evolution of the southern European Variscan belt: Exhumation of the lower crust in a context of oblique convergence. Comptes Rendus Geoscience, 341: 214-223.

Corsini, M., Bosse, V., Féraud, G., Demoux, A., Crévola, G., 2010. Exhumation processes during post-collisional stage in the Variscan belt revealed by detailed 40Ar/39Ar study (Tanneron Massif, SE France). International J.Earth Sci. 99: 327341.

Cortesogno, L., Gaggero, L., Oggiano, G., Paquette, J. L., 2004. Different tectono-thermal evolutionary paths in eclogitic rocks from the axial zone of the Variscan chain in Sardinia (Italy) compared with the Ligurian Alps. Ofioliti, 29(2): 125144.

Crevola, G., Pupin, J. P., 1994. Crystalline Provence: structure and Variscan evolution. In Pre-Mesozoic Geology in France and related areas (pp. 426-441). Springer Berlin Heidelberg.

Cruciani, G., Franceschelli, M., Elter, F. M., Puxeddu, M., Utzeri, D., 2008. Petrogenesis of Al-silicate-bearing trondhjemitic migmatites from NE Sardinia, Italy. Lithos, 102(3): 554-574.

Cruciani, G., Franceschelli, M., Groppo, C., 2011. P-T evolution of eclogite-facies metabasite from NE Sardinia, Italy: insights into the prograde evolution of Variscan eclogites. Lithos, 121(1): 135-150.

Cruciani, G., Franceschelli, M., Massonne, H. J., Carosi, R., Montomoli, C., 2013. Pressure-temperature and deformational evolution of high-pressure metapelites from Variscan NE Sardinia, Italy. Lithos, 175: 272-284.

Cruciani, G., Franceschelli, M., Langone, A., Puxeddu, M., Scodina, M., 2015. Nature and age of pre-Variscan eclogite protoliths from the Low-to Medium-Grade Metamorphic Complex of north-central Sardinia (Italy) and comparisons with 
Cundall, P., 1989. Numerical experiments on localization in frictional materials. Ingenieur-Archiv 59: 148-159.

Demoux, A., Schärer, U., Corsini, M., 2008. Variscan evolution of the Tanneron massif, SE-France, examined through U-Pb monazite ages. J. Geol. Soc. 165: $467-478$.

Di Vincenzo, G., Carosi, R., Palmeri, R., 2004. The relationship between tectono-metamorphic evolution and argon isotope records in white mica: constraints from in situ 40Ar-39Ar laser analysis of the Variscan basement of Sardinia. J. Petrology, 45(5): 1013-1043..

Duchesne, J.-C., Liégeois, J.-P., Bolle, O., Vander Auwera, J., Bruguier, O., Matukov, D.I., Sergeev, S. A., 2013. The fast evolution of a crustal hot zone at the end of a transpressional regime: The Saint-Tropez peninsula granites and related dykes (Maures Massif, SE France). Lithos, 162-163: 195-220.

Duprat-Oualid, S., Yamato, P., Pitra, P. 2013. Major role of shear heating in intracontinental inverted metamorphism: Inference from a thermo-kinematic parametric study. Tectonophysics, 608, 812-831.

Duretz T., Gerya T. V., 2013. Slab detachment during continental collision: Influence of crustal rheology and interaction with lithospheric delamination. Tectonophysics, 602: 124-140.

Duretz, T., Gerya, T. V., May, D. A., 2011. Numerical modelling of spontaneous slab break-off and subsequent topographic response. Tectonophysics, 502(1): 244-256.

Edel, J. B., Montigny, R., Thuizat, R., 1981. Late Paleozoic rotations of Corsica and Sardinia: new evidence from paleomagnetic and K-Ar studies. Tectonophysics, 79(3): 201-223.

Edel, J. B., Casini, L., Oggiano, G., Rossi, P., Schulmann, K. (2014). Early Permian $90^{\circ}$ clockwise rotation of the MauresEstérel-Corsica-Sardinia block confirmed by new palaeomagnetic data and followed by a Triassic $60^{\circ}$ clockwise rotation. Geol. Soc. London, Spec. Pub., 405(1), 333-361.

Elter, F. M., Corsi, B., Cricca, P., Muzio, G., 2004. The south-western Alpine foreland: correlation between two sectors of the Variscan chain belonging to "stable Europe": Sardinia (-) Corsica and the Maures Massif (south-eastern France). Geodinamica Acta, 17(1) : 31-40.

England, P. C., Richardson, S. W., 1977. The influence of erosion upon the mineral fades of rocks from different metamorphic environments. J. Geol. Soc. 134(2): 201-213.

Faccenda, M., Gerya, T. V., Chakraborty, S., 2008. Styles of post-subduction collisional orogeny: influence of convergence velocity, crustal rheology and radiogenic heat production. Lithos, 103(1), 257-287.

Fernandez, A., Laporte, D., 1991. Significance of low symmetry fabrics in magmatic rocks. J. Struct. Geol. $13(3)$ : 337-347.

Ferré, E. C., Leake, B. E., 2001. Geodynamic significance of early orogenic high-K crustal and mantle melts: example of the Corsica Batholith. Lithos, 59(1): 47-67.

Franceschelli, M., Puxeddu, M., Cruciani, G., Utzeri, D., 2007. Metabasites with eclogite facies relics from Variscides in Sardinia, Italy: a review. International Journal of Earth Sciences, 96: 795 - 815.

Ganne, J., Gerbault, M., Block, S., 2014. Thermo-mechanical modelling of lower crust exhumation-Constraints from the metamorphic record of the Palaeoproterozoic Eburnean orogeny, West African Craton. Precambrian Research, 243: 88109.

Gapais, D., Cagnard, F., Gueydan, F., Barbey, P., Ballevre, M. (2009). Mountain building and exhumation processes 
Gattacceca, J., Orsini, J. B., Bellot, J. P., Henry, B., Rochette, P., Rossi, P., Cherchi, G., 2004. Magnetic fabric of granitoids from Southern Corsica and Northern Sardinia and implications for Late Hercynian tectonic setting. J. Geol. Soc. 161(2): 277-289

Gattacceca J., Deino A., Rizzo R., Jones D.S., Henry B., Beaudoin B., Vadeboin F., 2007. Miocene rotation of Sardinia: New paleomagnetic and geochronological constraints and geodynamic implications. Earth and Planetary Science Letter, 258: 359-377.

Gerbault M. Willingshoffer, E., 2004. Lower crust indentation or horizontal ductile flow during continental collision? Tectonophysics 387(1) : 169-187.

Gerbault, M., Cembrano, J., Mpodozis, C., Farias, M., Pardo, M., 2009. Continental margin deformation along the Andean subduction zone: Thermo-mechanical models. Physics of the Earth and Planetary Interiors, 177(3), 180-205.

Gerya, T., Perchuk, L. L., van Reenen, D. D., Smit, C. A. (2000). Two-dimensional numerical modelling of pressuretemperature-time paths for the exhumation of some granulite facies terrains in the Precambrian. J. Geodynamics, 30(1) : 17-35.

Gerya, T., Perchuk, L.L., Burg, J.-P., 2008. Transient hot channels: Perpetrating and regurgitating ultrahigh-pressure, hightemperature crust-mantle associations in collision belts. Lithos 103: 236-256.

Giacomini, F., Bomparola, R. M., Ghezzo, C., 2005. Petrology and geochronology of metabasites with eclogite facies relics from NE Sardinia: constraints for the Palaeozoic evolution of Southern Europe. Lithos, 82(1): 221-248.

Giacomini, F., Dallai, L., Carminati, E., Tiepolo, M., Ghezzo, C., 2008. Exhumation of a Variscan orogenic complex: insights into the composite granulitic-amphibolitic metamorphic basement of south-east Corsica (France). J. Metamorphic Geology, 26: 403-436.

Godin, L., Grujic, D., Law, R. D., \& Searle, M. P. (2006). Channel flow, ductile extrusion and exhumation in. Geological Society, London, Special Publications, 268.

Goutorbe, B., Poort, J., Lucazeau, F., Raillard, S., 2011. Global heat flow trends resolved from multiple geological and geophysical proxies. Geophys. J. Int. 187(3), 1405-1419.

Gueguen, E., 1995. Segmentation des marges et processus d'amincissement crustal : l'exemple du bassin liguro-provencal. Unpublished Thesis, University of Brest, 309 p.

Handy M. R., Mulch A., Rosenau M., Rosenberg C. L., 2001. The role of fault zones and melts as agents of weakening, hardening and differentiation of the continental crust: a synthesis. Geol. Soc. London. Spec. Pub. 186(1): 305-332.

Helbing, H., Frisch, W., Bons, P. D., 2006. South Variscan terrane accretion: Sardinian constraints on the intra-Alpine Variscides. J. Struct. Geol. 28(7): 1277-1291.

Huber, C., Bachmann, O., \& Dufek, J. (2011). Thermo-mechanical reactivation of locked crystal mushes: Melting-induced internal fracturing and assimilation processes in magmas. Earth and Planetary Science Letters, 304(3), 443-454.

Huerta, A. D., Royden, L. H., Hodges, K. V., 1999. The effects of accretion, erosion and radiogenic heat on the metamorphic evolution of collisional orogens. J. Metamorphic Geology, 17, 349-366.

Jamieson, R. A., Unsworth, M. J., Harris, N. B., Rosenberg, C. L., Schulmann, K. (2011). Crustal melting and the flow of mountains. Elements, 7(4), 253-260. 
Khodakovskii, G., Rabinowicz, M., Ceuleneer, G., \& Trubitsyn, V. P. (1995). Melt percolation in a partially molten mantle mush: Effect of a variable viscosity. Earth and Planetary Science Letters, 134(3), 267-281.

Klemperer, S. L. (2006). Crustal flow in Tibet: geophysical evidence for the physical state of Tibetan lithosphere, and inferred patterns of active flow. Geolo. Soc Spec. Pub. London 268(1), 39-70.

Koulakov, I., Gordeev, E. I., Dobretsov, N. L., Vernikovsky, V. A., Senyukov, S., Jakovlev, A., \& Jaxybulatov, K. (2013). Rapid changes in magma storage beneath the Klyuchevskoy group of volcanoes inferred from time-dependent seismic tomography. J. Volc. Geo. Res., 263, 75-91.

Laporte, D., Fernandez, A., Orsini, J. B., 1991. Le complexe d'lle-Rousse, Balagne, Corse du Nord-Ouest: pétrologie et cadre de mise en place des granitoïdes magnésiopotassiques. Géol. de la France, 4: 15-30.

Lardeaux, J. M., Schulmann, K., Faure, M., Janoušek, V., Lexa, O., Skrzypek, E., Štípská, P., 2014. The Moldanubian Zone in the French Massif Central, Vosges/Schwarzwald and Bohemian Massif revisited: differences and similarities. Geol. Soc. London Spec. Pub. 405(1): 7-44.

Le Pourhiet, L., Huet, B., May, D. A., Labrousse, L., Jolivet, L., 2012. Kinematic interpretation of the 3D shapes of metamorphic core complexes. Geochem. Geophys. Geosys, 13(9), doi: 10.1029/2012GC004271.

Lexa, O., Schulmann, K., Janoušek, V., Štípská, P., Guy, a., Racek, M., 2011. Heat sources and trigger mechanisms of exhumation of HP granulites in Variscan orogenic root. J. Metamorphic Geol. 29: 79-102.

Li, X. H., Faure, M., Lin, W., 2014. From crustal anatexis to mantle melting in the Variscan orogen of Corsica (France): SIMS $\mathrm{U}-\mathrm{Pb}$ zircon age constraints. Tectonophysics, 634: 19-30.

Luth, S., Willingshofer, E., Sokoutis, D., \& Cloetingh, S. (2013). Does subduction polarity changes below the Alps? Inferences from analogue modelling. Tectonophysics, 582, 140-161.

Maierová, P., Lexa O., Schulmann K., Štípská P, 2014. Contrasting tectono-metamorphic evolution of orogenic lower crust in the Bohemian Massif: A numerical model. Gondwana Res. 25(2) : 509-521

Mareschal, J. C., Jaupart, C., 2013. Radiogenic heat production, thermal regime and evolution of continental crust. Tectonophysics, 609, 524-534.

Marotta, A. M., Spalla, M. I., 2007. Permian $\square$ Triassic high thermal regime in the Alps:Result of late Variscan collapse or continental rifting? Validation by numerical modelling. Tectonics 26 doi:10.1029/2006TC002047.

Ménot, R. P., Orsini, J. B., 1990. Evolution du socle anté-stéphanien de Corse: événements magmatiques et métamorphiques. Schweizerische Mineralogische und Petrographische Mitteilungen, 70(1): 35-53.

Mezri, L., Le Pourhiet, L., Wolf, S., Burov, E. (2015). New parametric implementation of metamorphic reactions limited by water content, impact on exhumation along detachment faults. Lithos, 236, 287-298.

Moussavou, M. 1998. Contribution à l'histoire thermo-tectonique Varisque du Massif des Maures, par la typologie du zircon et la géochronologie U/Pb sur minéraux accessoires, Unpublished Thesis, University of Montpellier, France.

Moghadam, R. H., Trepmann, C. A., Stöckhert, B., \& Renner, J. (2010). Rheology of synthetic omphacite aggregates at high pressure and high temperature. J. Petrology, doi: 10.1093/petrology/egq006.

Oliot, E., Melleton, J., Schneider, J., Corsini, M., Gardien, V., Rolland, Y., 2015. Variscan crustal thickening in the MauresTanneron massif (South Variscan belt, France): new in situ monazite U-Th-Pb chemical dating of high-grade rocks.

Bulletin de la Société Géologique de France, 186(2-3): 145-169.

35 Gerbault et al., november 2016 
Onézime, J., Faure, M., Crévola, G., 1999. Etude petro-structurale du complexe granitique Rouet - Plan-de-la-Tour (massifs des Maures et du Tanneron occidental, Var). C.R.A.S. 328: 773-779.

Orsini, J. B., 1980. Le batholite corso-sarde: un exemple de batholite hercynien (structure, composition, organisation d'ensemble). Sa place dans la chaîne varisque de l'Europe moyenne. Unpublished doctoral thesis, Université d'AixMarseille III, 370p.

Orsini, J. B., Cocirta, C., Zorpi, M. J., 1991. Genesis of mafic microgranular enclaves through differentiation of basic magmas, mingling and chemical exchanges with their host granitoid magmas. Enclaves and granite petrology. Developments in petrology, 13: 445-464.

Palagi, P., Laporte, D., Lardeaux, J. M., Menot, R. P., Orsini, J. B., 1985. Identification d'un complexe leptyno-amphibolique au sein des «gneiss de Belgodere» (Corse occidentale). Comptes rendus de l'Académie des sciences. Série 2, Sciences de la Terre, 301(14): 1047-1052.

Palmeri, R., Fanning, M., Franceschelli, M., Memmi, I., Ricci, C. A., 2004. SHRIMP dating of zircons in eclogite from the Variscan basement in north-eastern Sardinia (Italy). Neues Jahrbuch für Mineralogie-Monatshefte, 2004(6): 275-288.

Parsons, A. J., Phillips, R. J., Lloyd, G. E., Law, R. D., Searle, M. P., Walshaw, R. D. (2016). Mid-crustal deformation of the Annapurna-Dhaulagiri Himalaya, central Nepal: An atypical example of channel flow during the Himalayan orogeny. Geosphere, GES01246-1.

Paquette, J. L., Ménot, R. P., Pin, C., Orsini, J. B., 2003. Episodic and short-lived granitic pulses in a post-collisional setting: evidence from precise U-Pb zircon dating through a crustal cross-section in Corsica. Chemical Geology, 198(1): 1-20.

Perchuk, L.L., Gerya, T.V., Nozhkin, A.D., 1989. Petrology and retrogression in granulites of the Kanskiy Formation, Yenisey Range, Eastern Siberia. J.. Metam. Geol. 7 : 599 - 617.

Petford, N., Clemens, J. D., 2000. Granites are not diapiric!. Geology Today, 16(5): 180-184.

Platt, JP., 1993. Exhumation of high-pressure rocks: A review of concepts and processes. Terra Nova 5,119-133.

Poliakov, A. N. B., Cundall, P. A., Podladchikov, Y. Y., Lyakhovsky, V. A., 1993. An explicit inertial method for the simulation of viscoelastic flow: elastic effects on diapiric flow in two-and three-layers models. In Flow and Creep in the Solar System: observations, modelling and Theory (pp. 175-195). Springer Netherlands.

Rabinowicz, M.,Toplis, M. (2009). Melt segregation in the lower part of the partially molten mantle zone beneath an oceanic spreading centre: Numerical modelling of the combined effects of shear segregation and compaction. J. Petrology, 50(6), 1071-1106.

Replumaz, A., Capitanio, F. A., Guillot, S., Negredo, A. M., \& Villaseñor, A. (2014). The coupling of Indian subduction and Asian continental tectonics. Gondwana Research, 26(2), 608-626.

Rey, P. F., Teyssier, C., Whitney, D. L., 2009. The role of partial melting and extensional strain rates in the development of metamorphic core complexes. Tectonophysics, 477(3): 135-144.

Rolland Y., Corsini M., Demoux A., 2009. Metamorphic and structural evolution of the Maures-Tanneron massif (SE Variscan): evidence of doming along a transpressional margin. Bull. Soc. Geol. France, 180: 217-230.

Rosenberg, C. L., Handy, M. R. (2005). Experimental deformation of partially melted granite revisited: implications for the continental crust. J. Metamorphic Geology, 23(1), 19-28, doi:10.1111/j.1525-1314.2005.00555.x.

Rosenberg, C. L., Brun, J. P., Cagnard, F., Gapais, D., 2007. Oblique indentation in the Eastern Alps: insights from 
laboratory experiments. Tectonics, 26(2), doi: 10.1029/2006TC001960.

Rossi, P., Cocherie, A., 1991. Genesis of a Variscan batholith: field, petrological and mineralogical evidence from the Corsica-Sardinia batholith. Tectonophysics, 195(2) : 319-346.

Rossi, P., Oggiano, G., Cocherie, A., 2009. A restored section of the "southern Variscan realm" across the Corsica-Sardinia microcontinent. Comptes Rendus Geoscience, 341(2) : 224-238.

Schmalholz, S. M., Medvedev, S., Lechmann, S. M., Podladchikov, Y., 2014. Relationship between tectonic overpressure, deviatoric stress, driving force, isostasy and gravitational potential energy. Geophys. J. Int. 197(2): 680-696.

Schneider J., Corsini M., Reverso Peila A., Lardeaux J.-M., 2014. Thermal and mechanical evolution of an orogenic wedge during Variscan collision: an example in the Maures-Tanneron Massif (SE France). Geol. Soc. London Spec. Pub. 405: SP405-4.

Schulmann, K., Konopásek, J., Janoušek, V., Lexa, O., Lardeaux, J.M., Edel, J.B., Štípská, P, Ulrich, S., 2009. An Andean type Palaeozoic convergence in the Bohemian Massif. Comptes Rendus Geoscience 341: 266-286.

Searle M.P, 2015. Mountain Building, Tectonic Evolution, Rheology, and Crustal Flow in the Himalaya, Karakoram, and Tibet. In G. Schubert (ed.) Treatise on Geophysics, Vol 6. Oxford: Elsevier; p. 469-511.

Searle, M. (2013). Crustal melting, ductile flow, and deformation in mountain belts: Cause and effect relationships. Lithosphere, 5(6), 547-554

Secchi, F. A., Brotzu, P., Callegari, E., 1991. The Arburese igneous complex (SW Sardinia, Italy)-an example of dominant igneous fractionation leading to peraluminous cordierite-bearing leucogranites as residual melts. Chem. Geol. 92(1): 213249.

Sokoutis, D., Burg, J. P., Bonini, M., Corti, G., Cloetingh, S., 2005. Lithospheric-scale structures from the perspective of analogue continental collision. Tectonophysics, 406(1): 1-15.

Spalla, M. I., Zanoni, D., Marotta, A. M., Rebay, G., Roda, M., Zucali, M., Gosso, G., 2014. The transition from Variscan collision to continental break-up in the Alps: insights from the comparison between natural data and numerical model predictions. Geological Society, London, Special Publications, 405(1), 363-400.

Thévoux-Chabuel, H., Ménot, R.P., Lardeaux, J.M., Monnier, O., 1995. Evolution tectono-métamorphique polyphasée paléozoïque dans le socle de Zicavo (Corse du Sud): témoin d'un amincissement post-orogénique. Comptes Rendus de l'Académie des Sciences de Paris, 321: 47-56

Thompson A. B., Connolly J. A., 1995. Melting of the continental crust: some thermal and petrological constraints on anatexis in continental collision zones and other tectonic settings. J. Geophys. Res.100(B8): 15565-15579.

Thompson, A.B., Schulmann, Karel, Jezek, J., 1997. Thermal evolution and exhumation in obliquely convergent (transpressive) orogens. Tectonophysics 280: 171-184.

Tirel, C., Brun, J. P., Burov, E., 2008. Dynamics and structural development of metamorphic core complexes. J. Geophys. Res., 113, doi: B04403\r10.1029/2005jb003694.

Tommasini, S., Poli, G., Halliday, A. N, 1995. The role of sediment subduction and crustal growth in Hercynian plutonism: isotopic and trace element evidence from the Sardinia-Corsica batholith. J.Petrology 36(5) 1305-1332.

Turcotte, D.L., Schubert, G., 2002. Geodynamics. Second Edition. Cambridge ed. 450 p.

Ueda, K., Gerya, T. V., Burg, J. P. (2012). Delamination in collisional orogens: Thermomechanical modelling. Journal of 
Geophysical Research: Solid Earth, 117(B8), doi: 10.1029/2012JB009144.

Vanderhaeghe O., Medvedev S., Fullsack P., Beaumont C., Jamieson R. A., 2003. Evolution of orogenic wedges and continental plateaux: insights from crustal thermal-mechanical models overlying subducting mantle lithosphere. Geophys. J. Int. 153(1) : 27-51.

Vigneresse J. L., Barbey, P., Cuney, M., 1996. Rheological transitions during partial melting and crystallization with application to felsic magma segregation and transfer. J. Petrology, 37(6): 1579-1600.

Vigneresse J.L, 2006. Granitic batholiths: from pervasive and continuous melting in the lower crust to discontinuous and spaced plutonism in the upper crust. Transact. Royal Soc. Edinburgh, 97: 311-324.

Von Raumer, J. F., Stampfli, G. M., Bussy, F., 2003. Gondwana-derived microcontinents-the constituents of the Variscan and Alpine collisional orogens. Tectonophysics, 365(1): 7-22.

Vorhies, S. H., Ague, J. J., 2011. Pressure-temperature evolution and thermal regimes in the Barrovian zones, Scotland. J. Geol. Soc. 168(5): 1147-1166.

Weil, A.B., Gutiérrez-Alonso, G., Johnston, S.T., Pastor-Galán, D., 2013. Kinematic constraints on buckling a lithosphericscale orocline along the northern margin of Gondwana: A geologic synthesis. Tectonophysics, 582: 25-49.

Weinberg, R. F., Podladchikov, Y. Y., 1995. The rise of solid-state diapirs. J. Struct. Geol. 17(8): 1183-1195.

Yamato, P., Burov, E., Agard, P., Le Pourhiet, L., Jolivet, L., 2008. HP-UHP exhumation during slow continental subduction: Self-consistent thermodynamically and thermomechanically coupled model with application to the Western Alps. Earth Planet/ Sci. Lett. 271: 63-74. 
b)

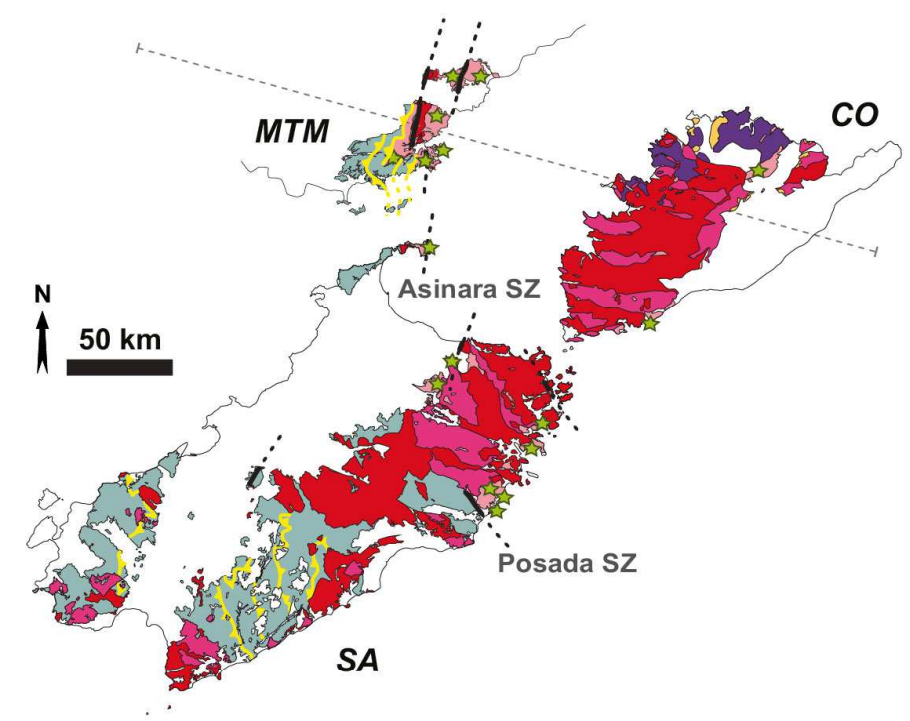

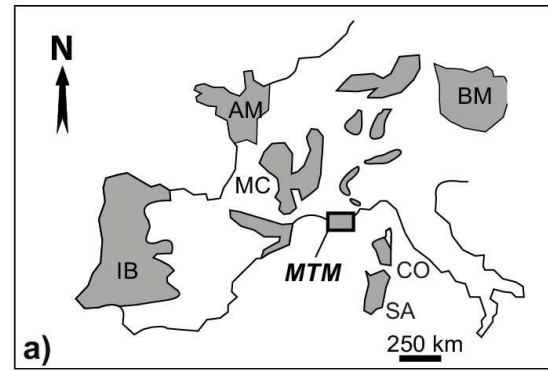

c)

Tanneron Massif La Moure fault Joyeuse fault,
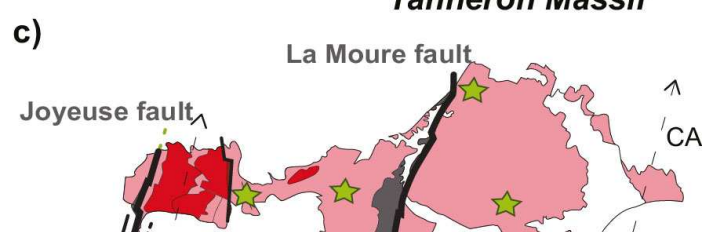

La Garde Freinet HA
Post-Carboniferous formations
Carboniferous basin
U2b granitoids
U2a granitoids
U1 granitoids

Migmatitic Internal Zone

Non-migmatitic External Zone

Pan-African basement

$\sim$ Migmatites

- Meta-tholeiitic rocks with HP relics

Overprinted eclogites occurences

$\checkmark$ Sinistral "̋ Dextral wrenching

Thrusting Normal faulting

$v^{\lambda}$ Anfiform axis
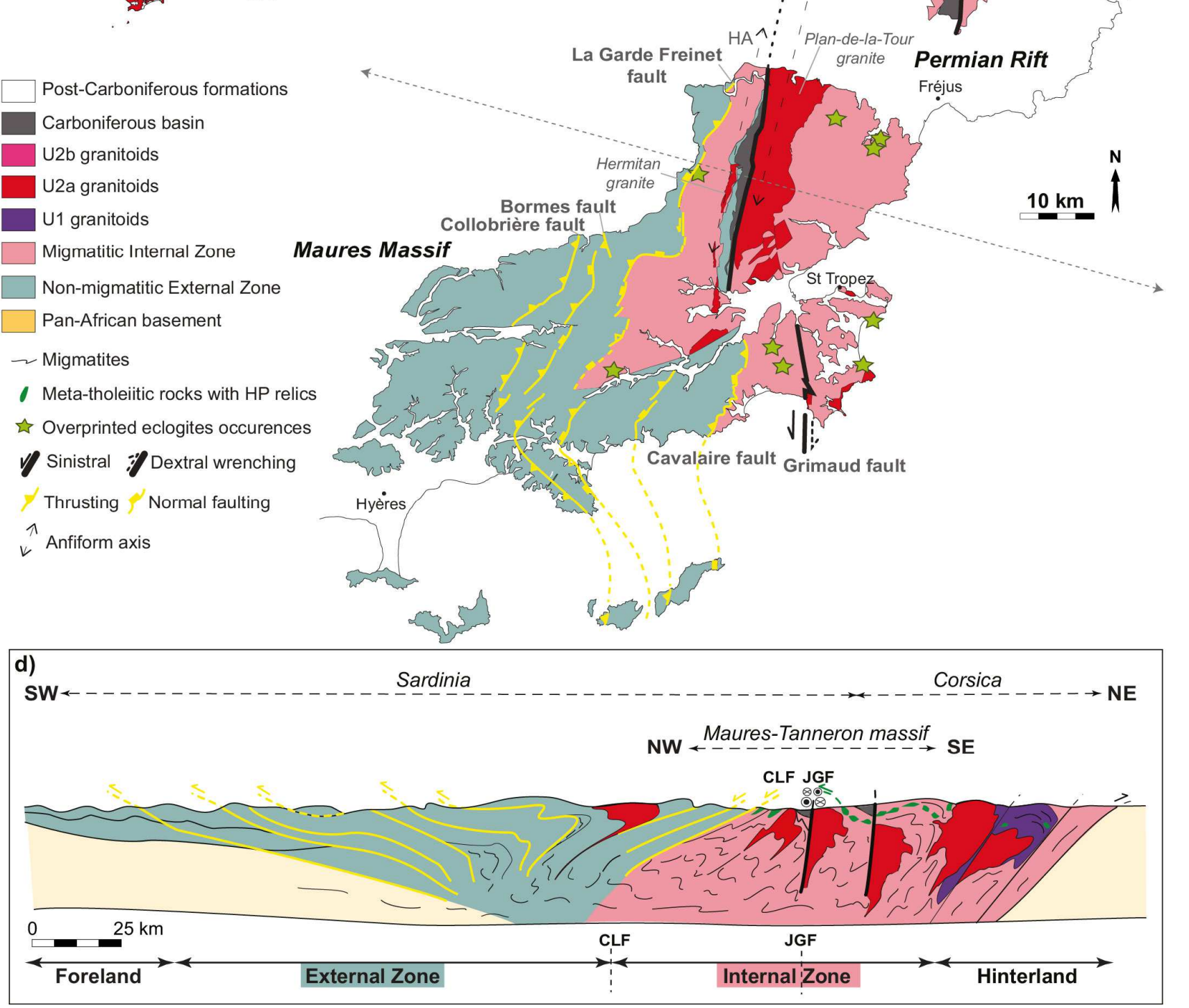

Figure 1: a) Main Variscan massifs outcropping in Western Europe. (BM) Bohemian Massif, (AM) Armorican Massif, (MC) Massif Central, (IM) Iberian Massif, (CO) Corsica, (SA), Sardinia, (MTM) Maures-Tanneron Massif. b) Simplified geological map of the Southern European Variscan Belt (SEVB) including Corsica, Sardinia and the Maures-Tanneron Massif. A 55 clockwise rotation as been applied to CO and SA to put the massifs in their relative position to the MTM at the end of 
Variscan Orogeny (Gueguen, 1995; Gattacceca et al., 2007). Modified after Cocherie et al., 1994; Carmignani et al., 2001; Paquette et al., 2003; Carosi et al., 2012; Musumeci et al., 2014; Casini et al., 2015; Oliot et al., 2015. c) Simplified geological map of the MTM highlighting the External and Internal Zones, main granitoids plutons and main fault zones, modified after Schneider et al. (2014). (HA) Hermitan antiform, (RA) Rouet antiform, (CA) Cannes antiform. d) Interpretative cross section through the Southern European Variscan Chain modified after Schneider et al. (2014). (CLF) Cavalaire-La Garde Freinet fault zone, (JGF) Joyeuse-Grimaud fault zone. 
(a) DOa at $420 \mathrm{Ma}$

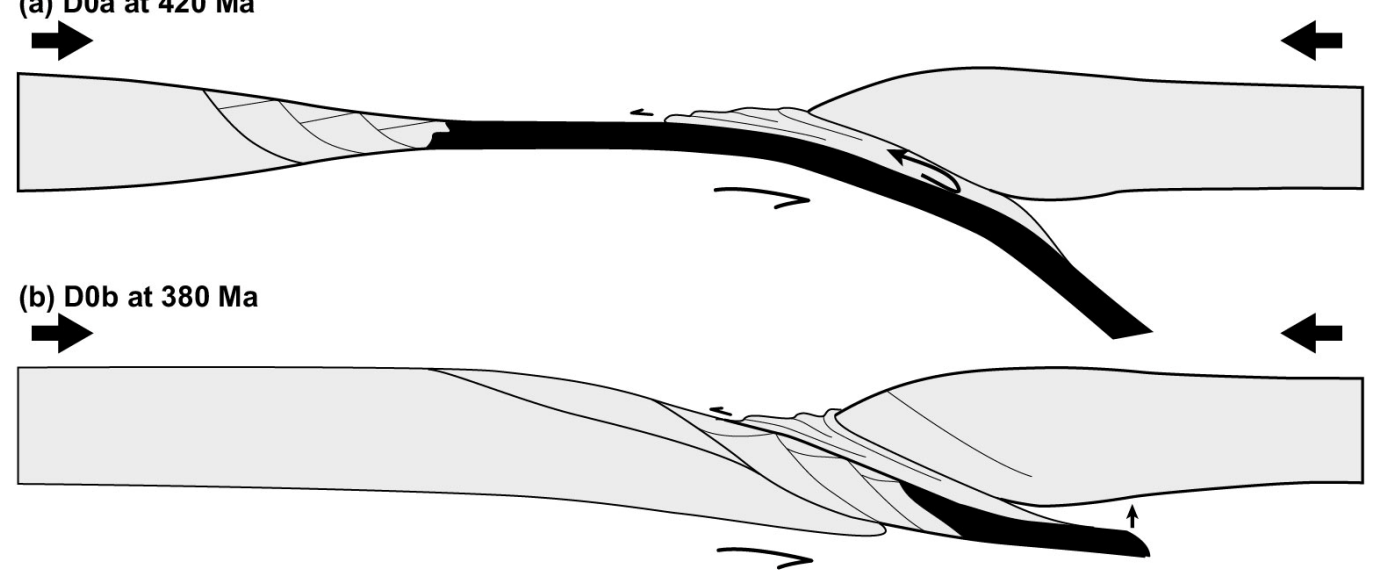

(c) D1 at $360 \mathrm{Ma}$
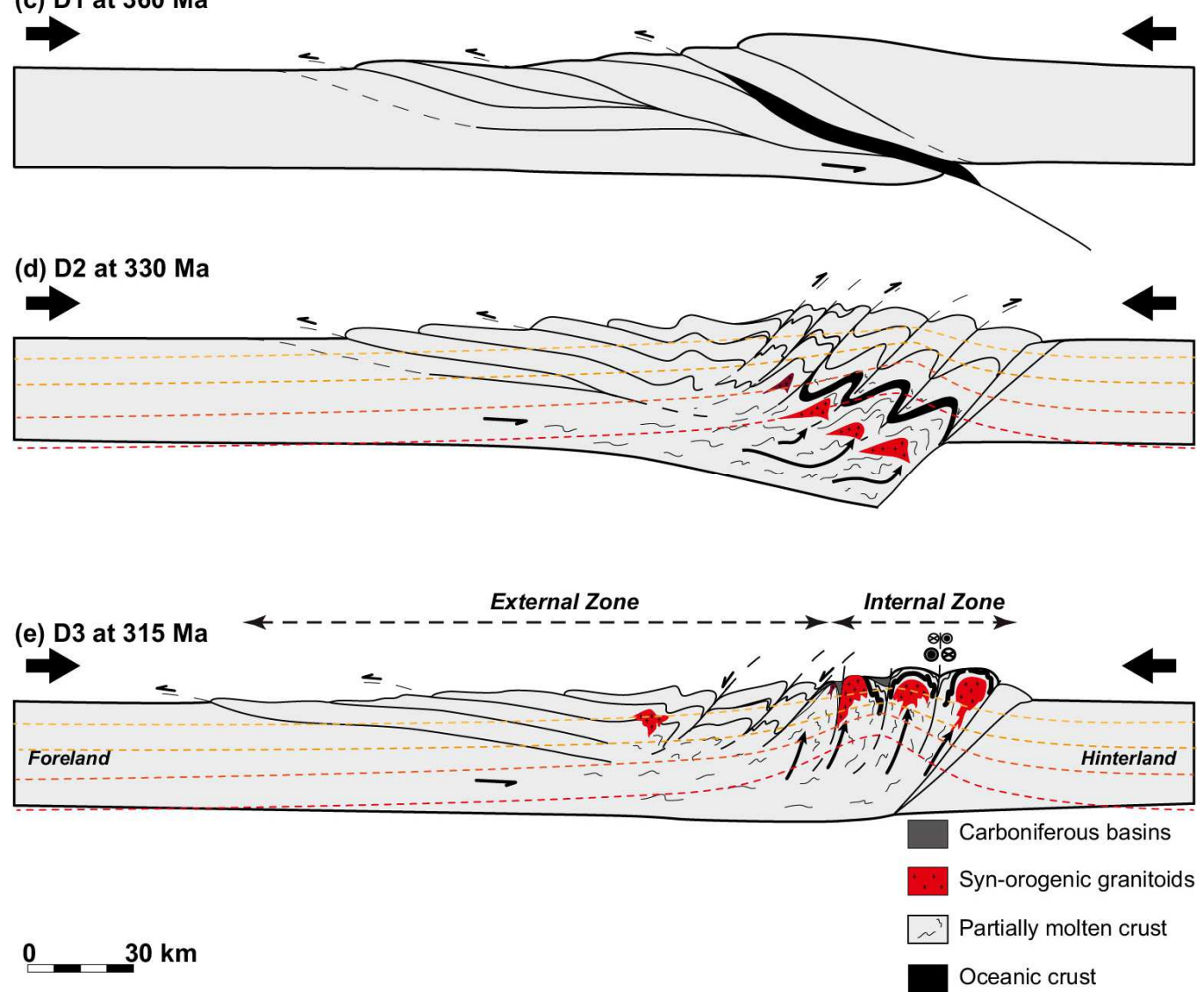

Figure 2: Conceptual geodynamic evolution of the MTM, modified after Schneider et al. (2014). The dashed red lines represent the schematic geometry of isotherms. The numerical study focuses on stage D2. 


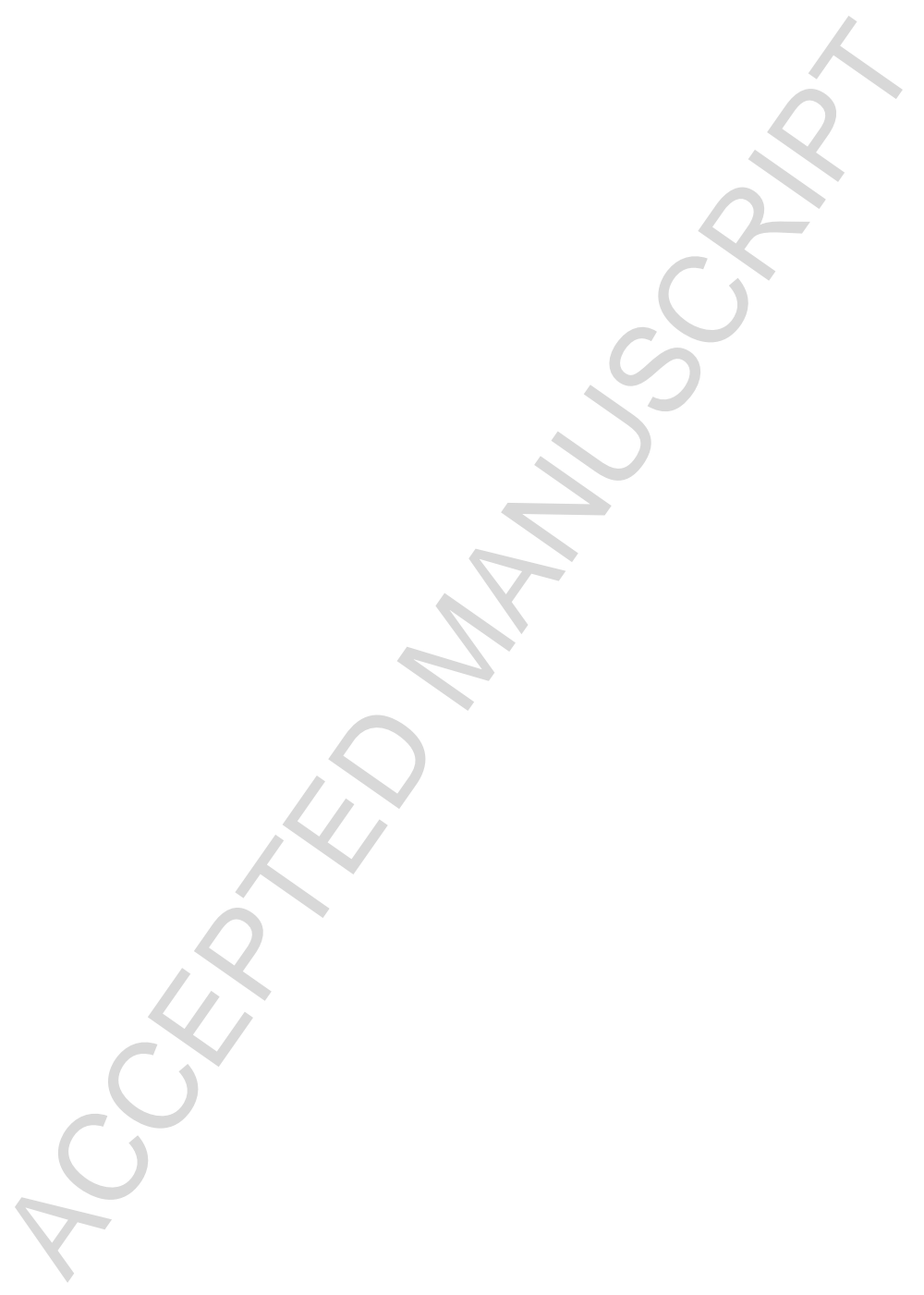


a)
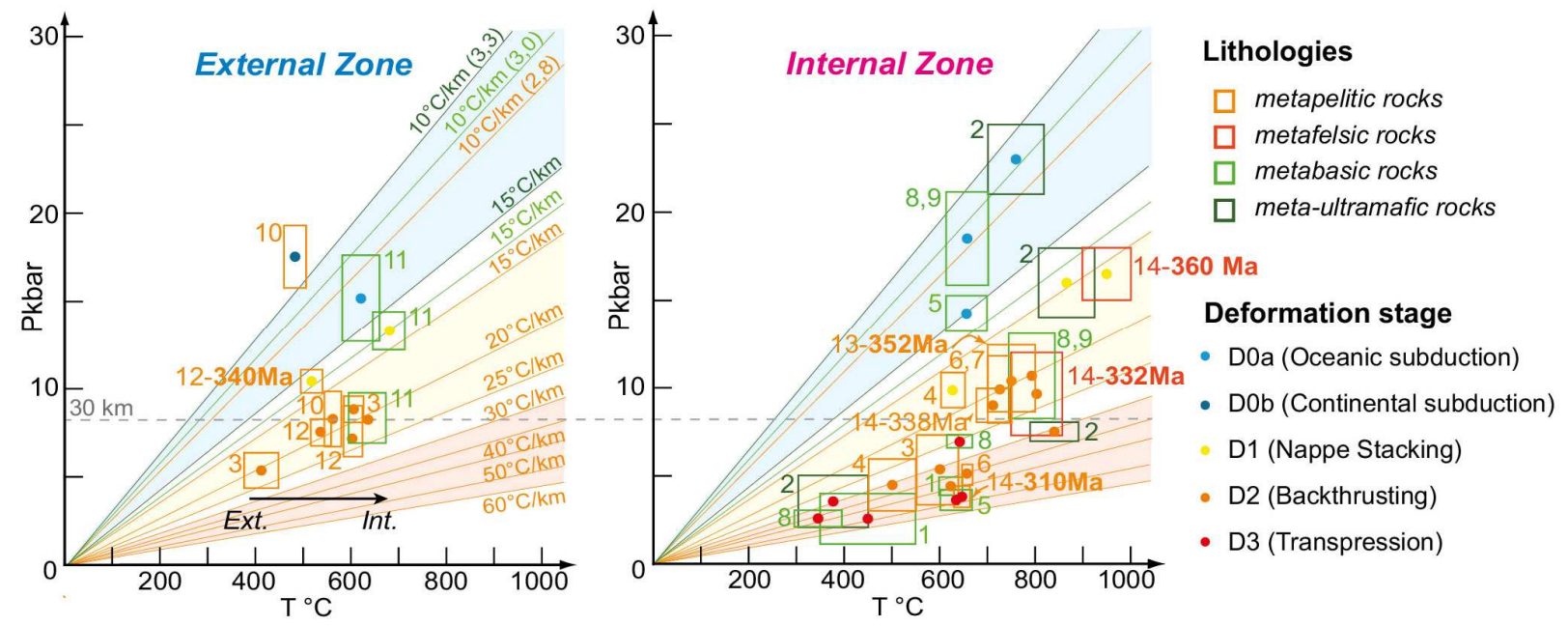

b) Evolution of the apparent thermal gradient

"."." Oceanic subduction

External Zone

Internal Zone

$x . x^{\circ} \mathrm{C} / \mathrm{km} / \mathrm{Ma}$ - rate of elevation

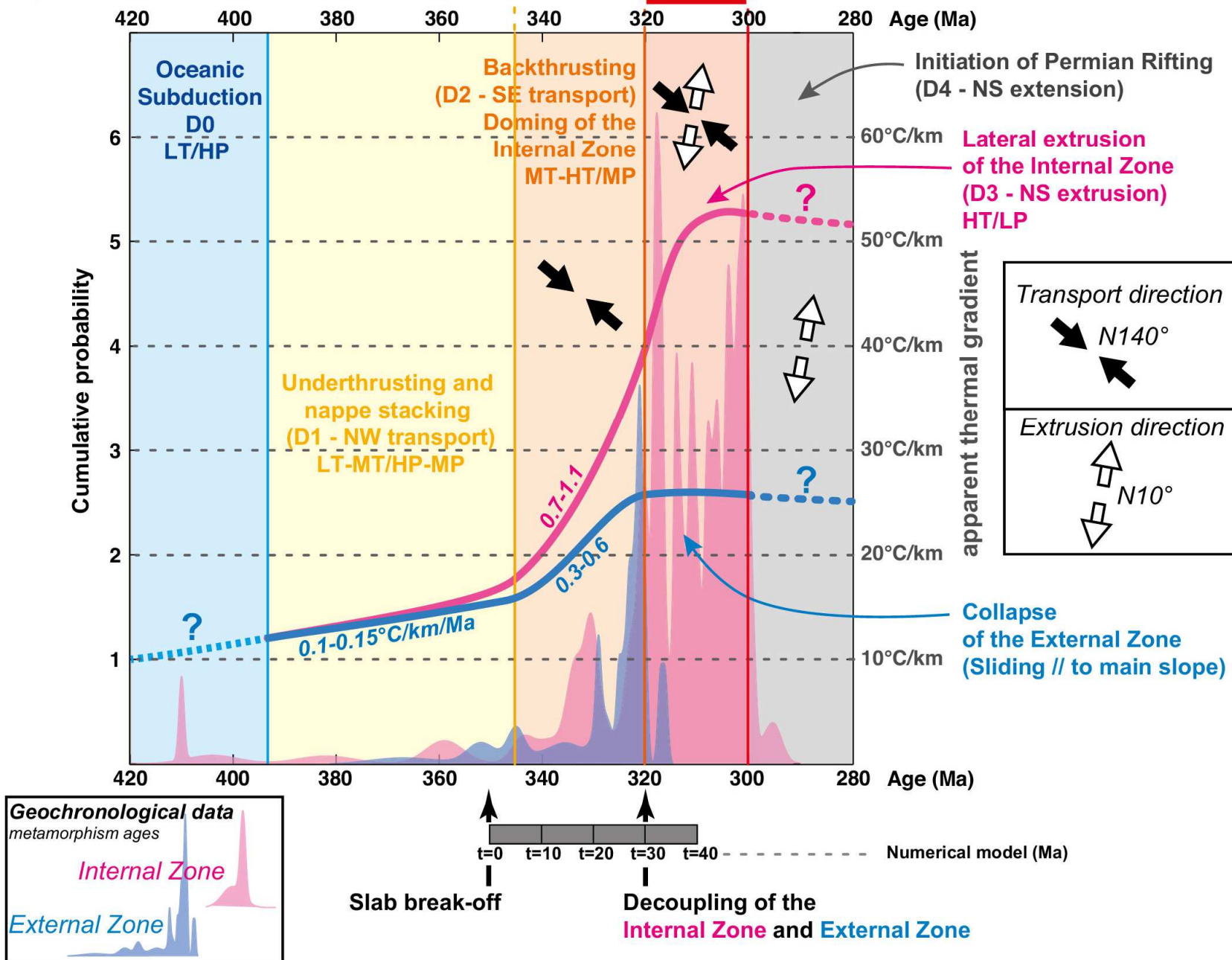

Figure 3: a) Compilation of the available metamorphic data in the MTM, Sardinia and Corsica, relatively to their location (External vs. Internal Zone), protolith (color of the boxes), and deformation stage (color of the dots). The apparent thermal gradient is also shown, calculated for three different average densities of the lithological section : $3.3\left(\mathrm{~kg} / \mathrm{m}^{3}\right)$ best representing deeply buried rocks in the mantle, 3.0 best representing average density of the lower crust in subduction zones 
and 2.8 best representing the average density in an orogenic wedge. When the metamorphic stage of a sample has been dated, the age is also given. The arrow pointing from Ext. to Int. shows the relative position of the ploted samples in the External Zone. (1) Bellot et al., 2002, (2) Bellot et al., 2005, (3) Buscail 2000, (4) Carosi et al., 2009, (5) Cortesogno et al., 2004, (6-7) Cruciani et al. 2008, (8-9) Cruciani et al., 2011, (10) Cruciani et al., 2013, (11) Cruciani et al., 2015, (12) Di Vincenzo et al, 2004, In situ Ar/Ar dating on muscovite 340Ma, (13) Giacomini et al., 2005, U/Pb LAM-ICPMS zircon 352+/3Ma, (14) Giacomini et al, 2008, U/Pb ELA-ICPMS zircon 361+/-3Ma ; 338+/-4Ma ; 332+/-4Ma ; Monazite c. 310+/-2Ma. b) Geochronological synthesis (together with Table1). At the bottom along the horizontal axis are reported the metamorphic geochronoligal data for the MTM and the Corsica-Sardinia domain, height represents the number of obtained ages, indicating the relative knowledge of events. The ages have been regrouped and distinguished for the Internal (pink) and the External (light blue) Zones and pinpoint the clear disconnection between these two domains at the end of the orogeny. Regarding the age of the magmatism (restricted to granitoids emplacement), the distribution frequency histogram hasn't been chosen because of the lack of the volume of the pluton representativeness of the dataset. For instance, in Corsica, for the main plutonism (Red granitoids U2a on map Fig.1), only one age is available (Urbalacone Pluton, Paquette et al., 2003), whereas 6 ages are available for later magmatism of smaller volumes (Pink granitoids U2b on map Fig.1). Therefore we choose to represent with boxes of variable size the time of activity of each type of magmatism (U1, U2a, U2b, U3 explanation in text), while boxes thickness represents the relative volume of outcropping plutons. The link between the geochronological data and the PT data allowed us to calculate the elevation rate of the apparent thermal gradient in each zone during each stage (blue and pink plain lines), rising by an order of magnitude from 340 Ma to 320 Ma. Black and white arrows show the main direction of transport, extrapolated to the main direction of convergence, and the main direction of extrusion (or lateral flow) deduced from field analyses reported in the literature. Geochronological dataset available in Supplementary Material. 


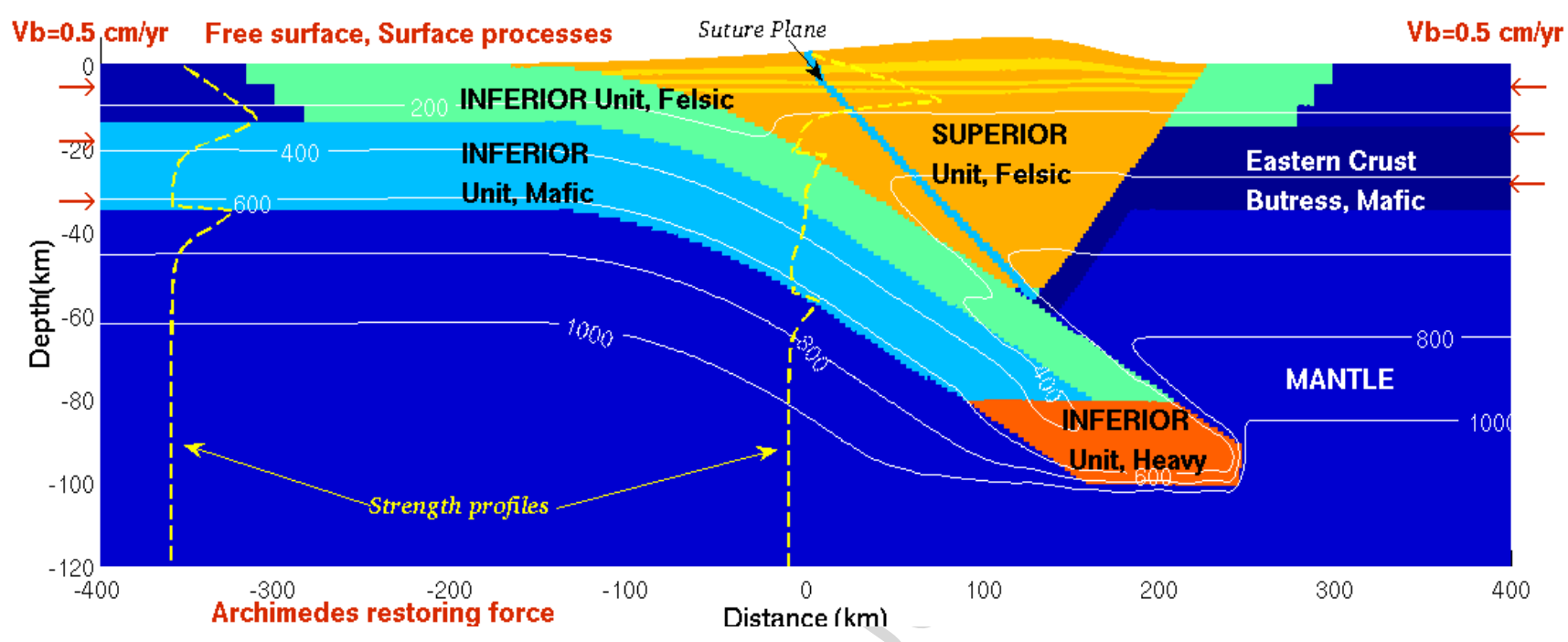

a)
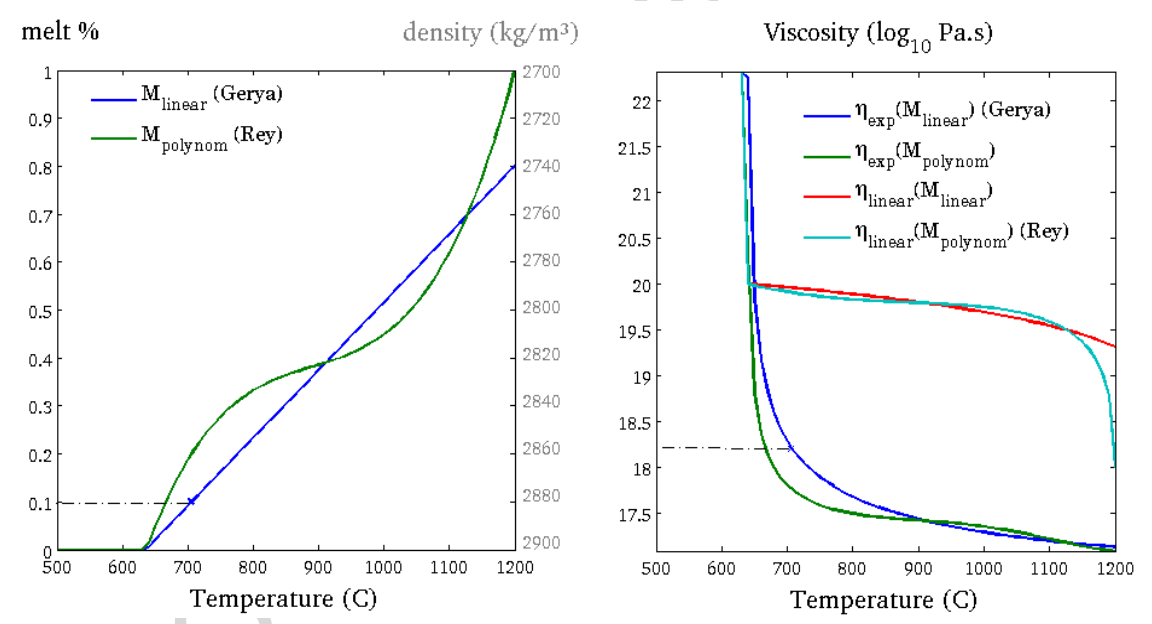

b)

Figure 4: a) Numerical setup, zoom (the modelled domain actually has a width of $1800 \mathrm{~km}$ and depth $150 \mathrm{~km}$ ), displaying the initially unmolten rheological units in the orogenic initial geometry. White contours are initial isotherms, red dotted vertical profiles in the center and on the border of the domain represent standard strength envelop (prior to melting). b) Dependency of viscosity and density upon melting percentage according to Equations 5,6 and 8 (see Appendix B for details) used by Gerya et al. (2008) and Rey et al. (2009). 

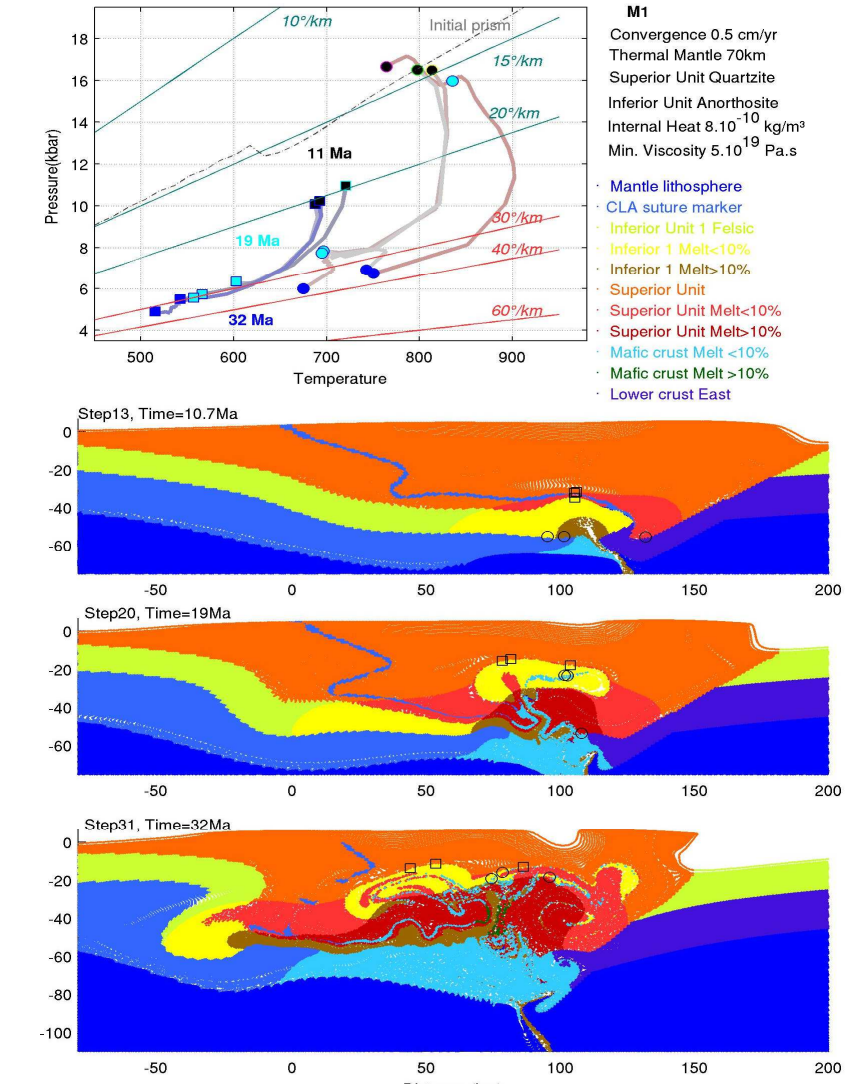

a)
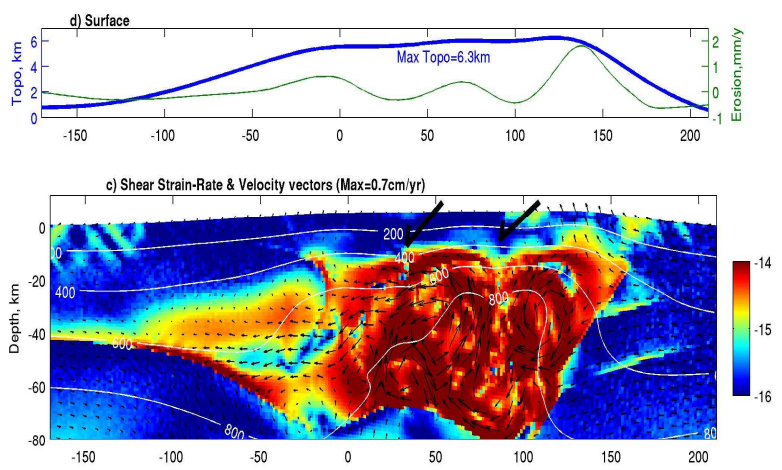

b) Viscosity (MPa) \& $\sigma$, orientations
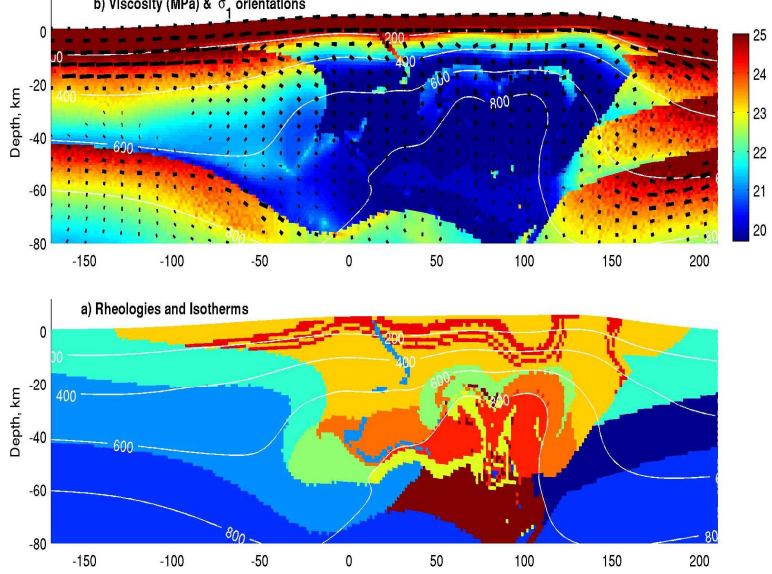

b)

M1, Time $=27$ Myrs, Shortening= $136 \mathrm{~km}$

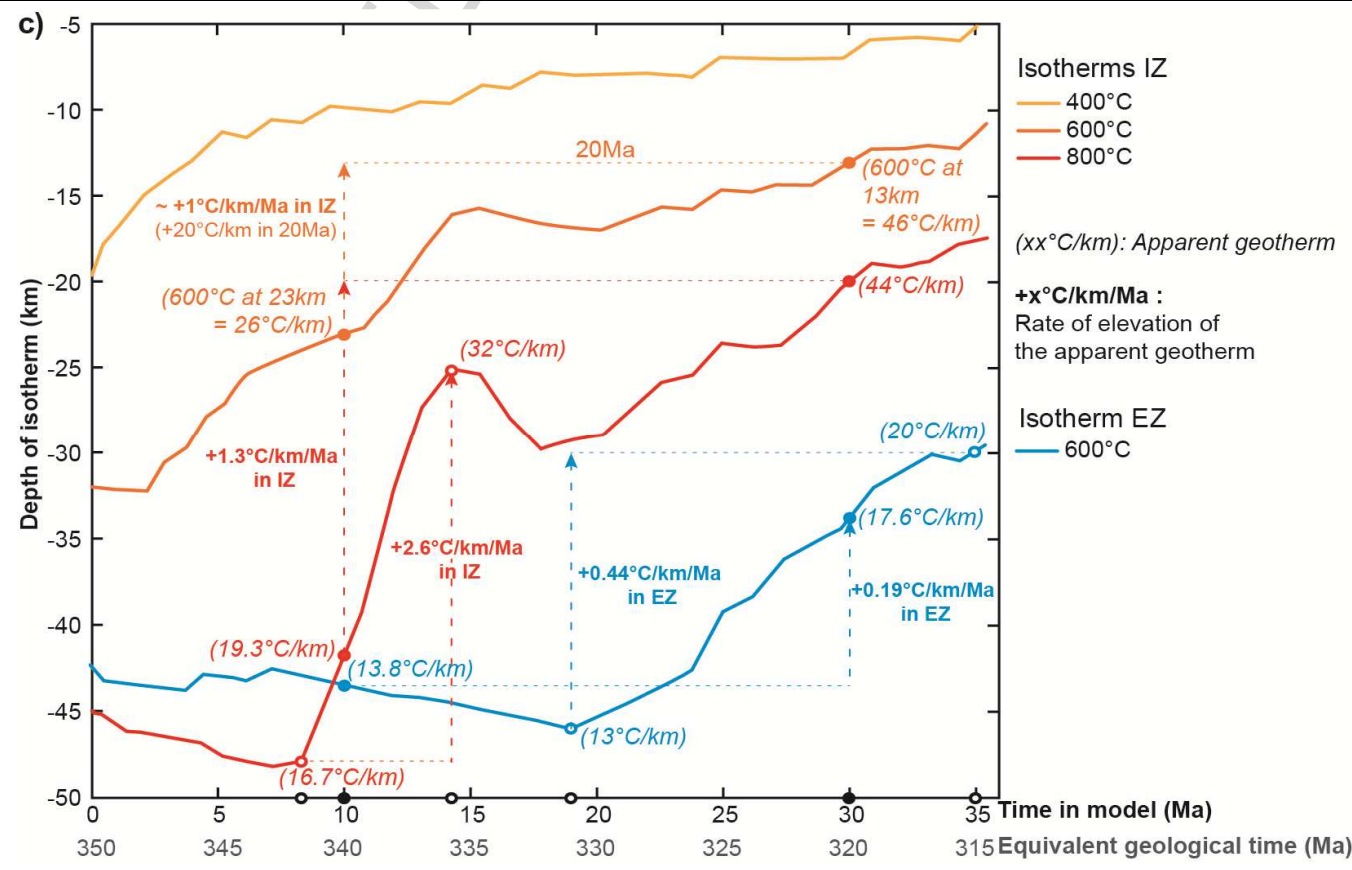

Figure 5: Reference model $\mathbf{M 1}$, with radiogenic heating, $M L=70 \mathrm{~km} 900^{\circ} \mathrm{C}$ isotherm, felsic and mafic rheological units, and convergence $\mathrm{Vb}=0.5 \mathrm{~cm} / \mathrm{yr}$. a) 3 Snapshots at times 10, 20, $30 \mathrm{Myr}$ (plot of passive markers) and PTt patterns for 8 markers distributed in the exhumed lower crust. Circles characterise deep initial domains that concentrate in the Internal zone (IZ), as opposed to square markers which are in the external zone (EZ). Legend displays color of layers and their melting equivalent. b) The central crust after 25 Myrs, plotted on the Lagrangian grid: bottom panel illustrates a second rising dome (yellow) embedded in the first one (green), and the folding and retrothrusting of the overriding upper crust. Middle: Viscosities and orientation of most compressive principal stress (black lines). The competent domains border the weak center from $10 \mathrm{~km}$ depth. Top: shear strain rate, velocity vectors, topography and erosion rate illustrating advective cell flow 
in the orogenic wedge and localised shear bands in the top $10 \mathrm{~km}$. Black arrows around X 50km indicate the sense of relative motion of the competent upper crust as opposed to the underlying warm lower crust, associated with $90^{\circ}$ rotations of the stress field. c) Evaluation of the apparent geothermal gradient to compare with data synthesis Fig. 3a. They are evaluated by assuming a linear dependency of temperature with depth at given depth, divided by the time-span in between 2 measurements. For each IZ and EZ, estimates provide an average rate over $20 \mathrm{Myr}$ as well as a maximum rate. 

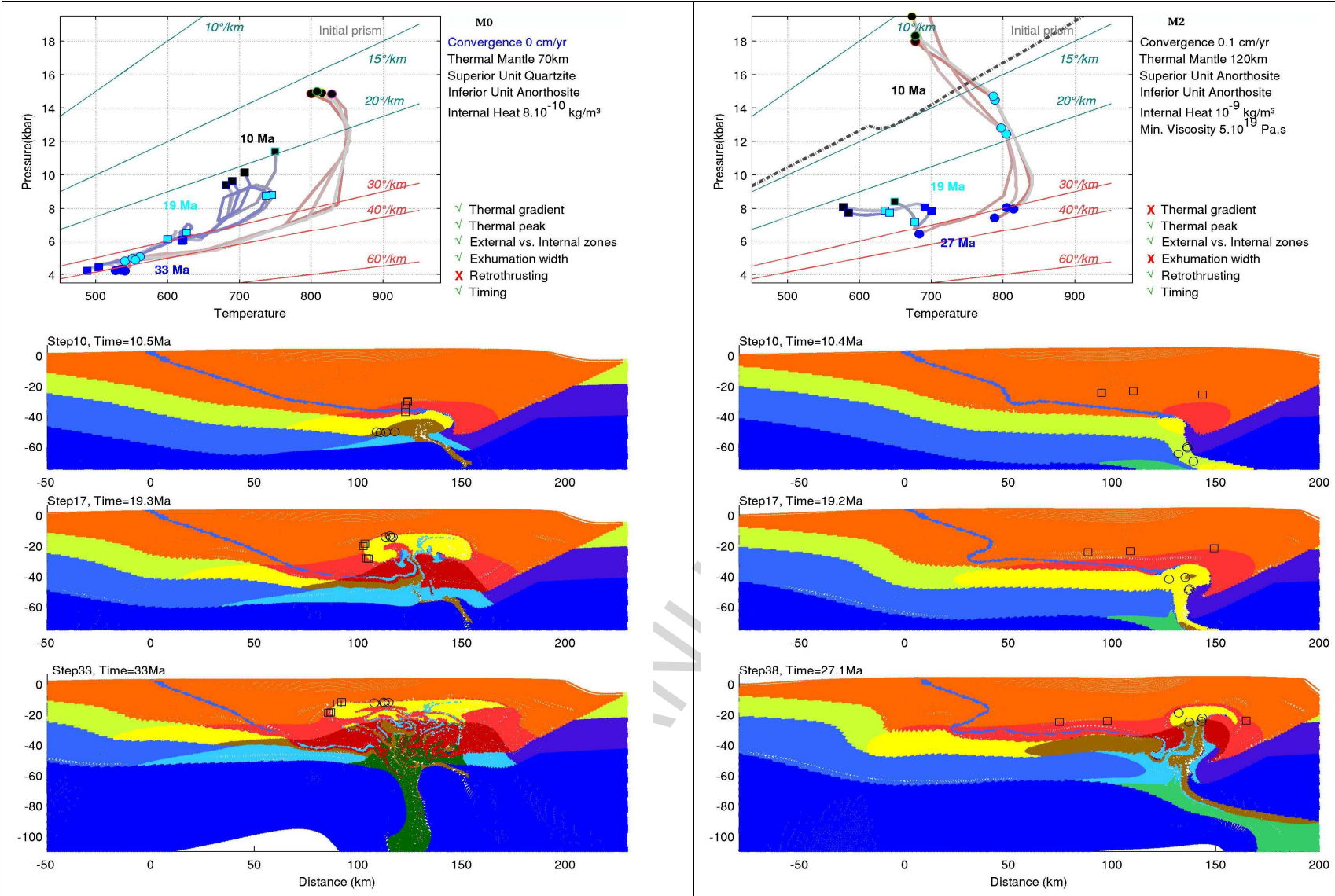

a) M0

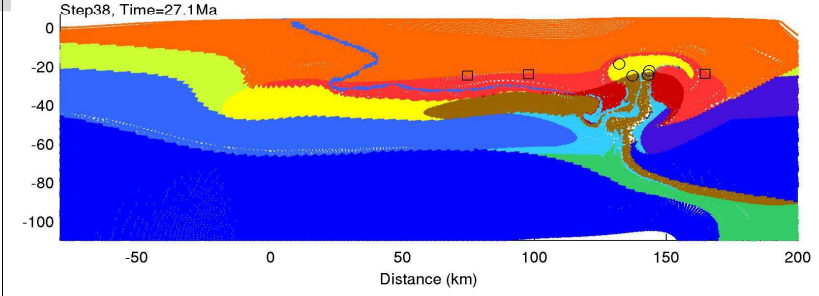

b) M2
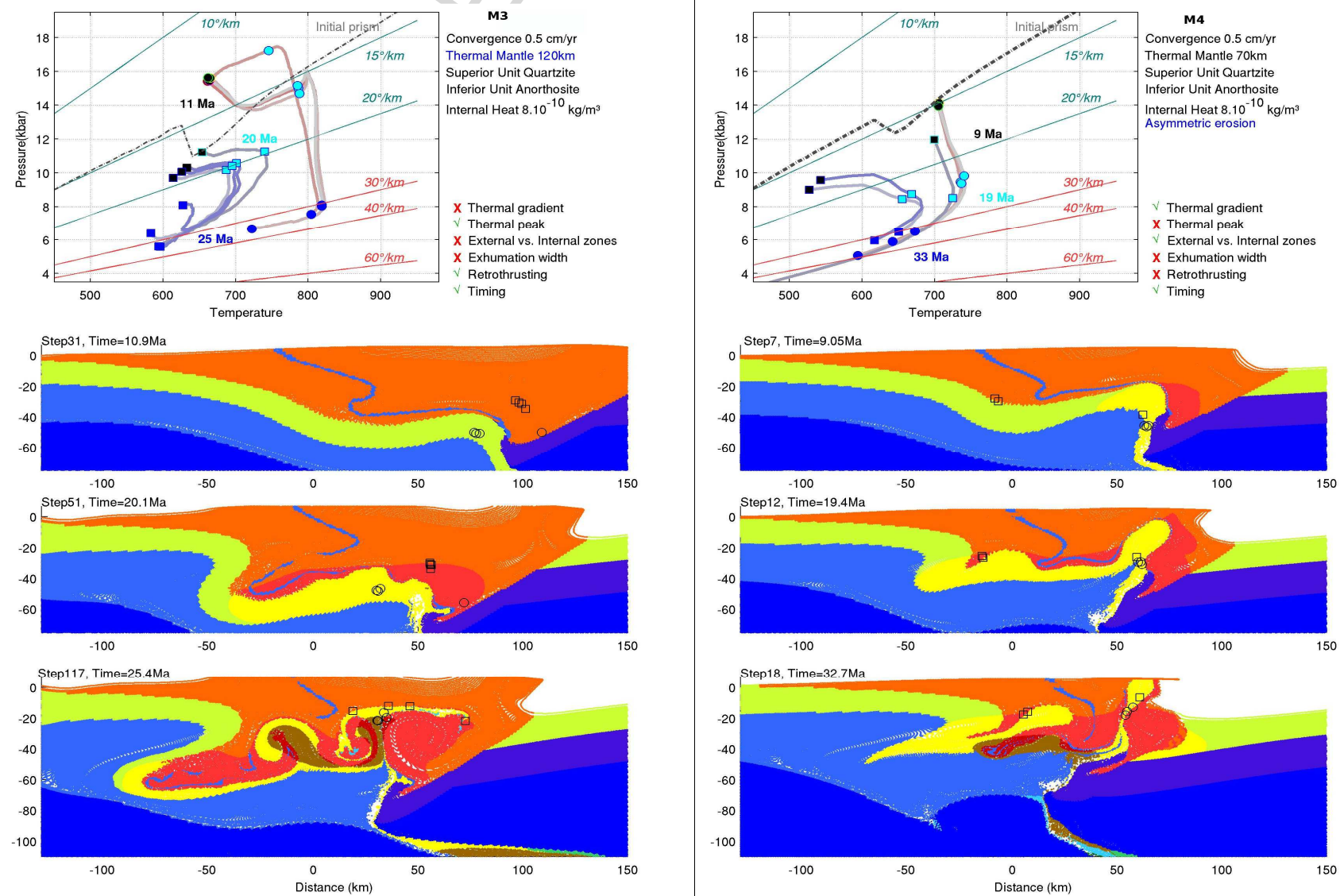

c) M3

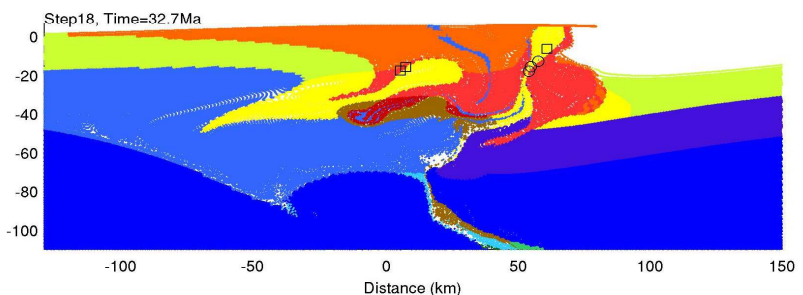

d) M4

Figure 6 : Models displaying the influence of boundary velocities: a)M1, b) M2, thermal mantle depth with $1 \mathrm{~mm} / \mathrm{yr}$ 
convergence rate (c) M3), and asymmetric strong surface processes (d) M4). See text and Tables 2 for details.

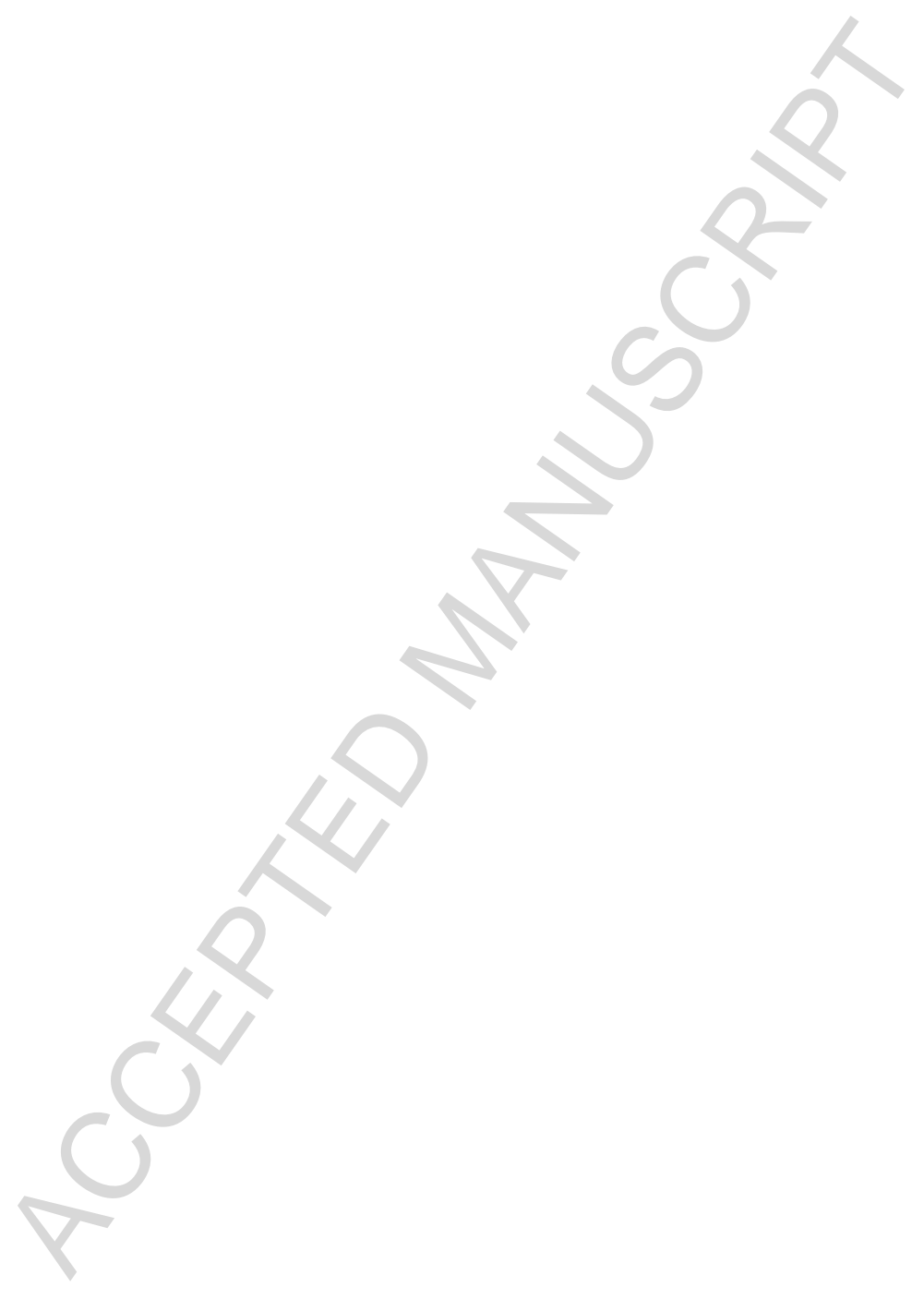

49 Gerbault et al., november 2016 

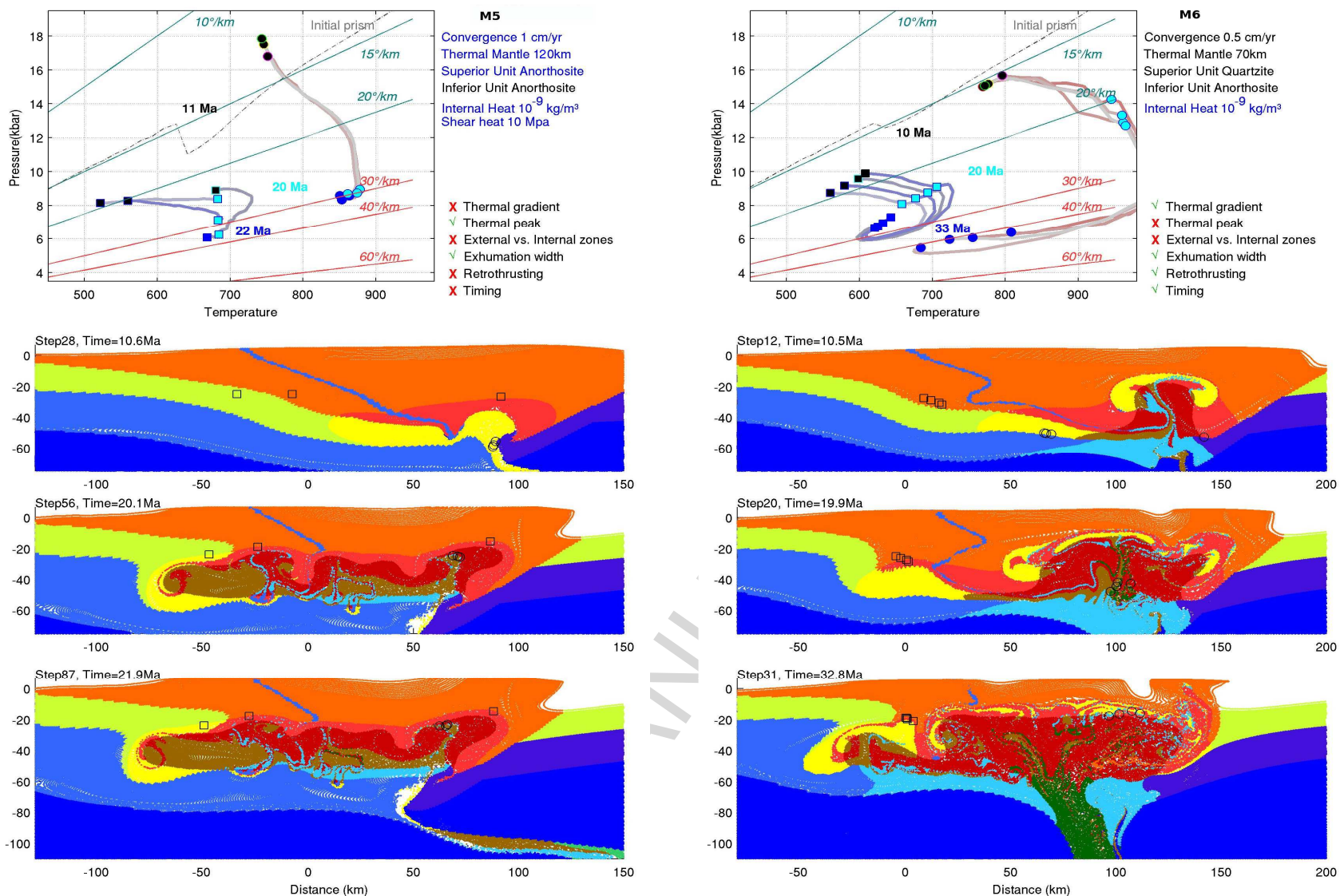

a) M5
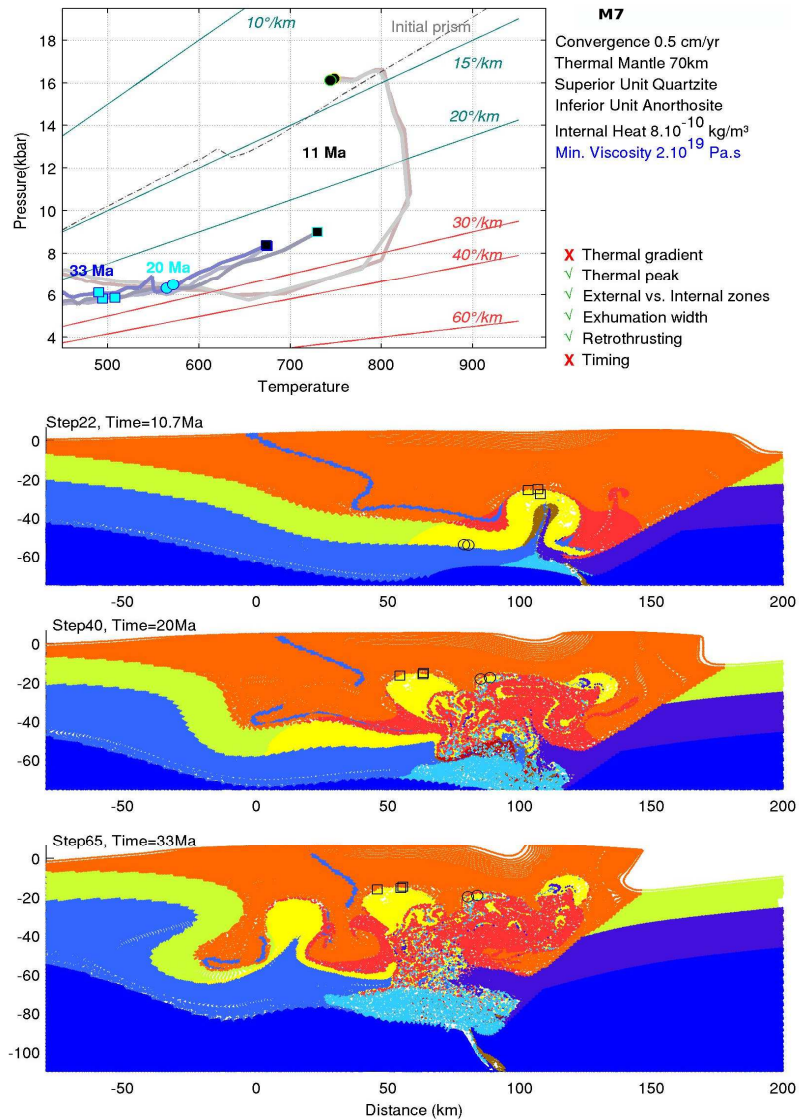

c) $\mathrm{M} 7$ b) M6
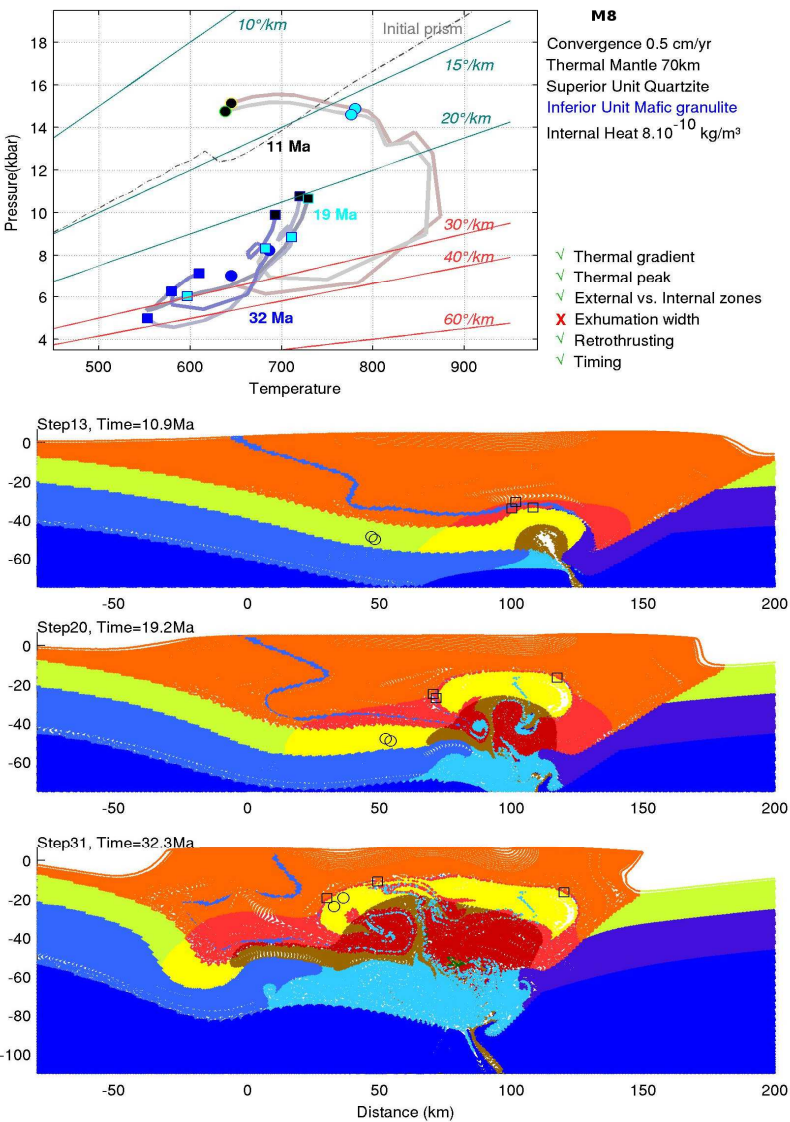

d) $\mathrm{M} 8$

Figure 7: Models displaying the influence of lower crustal strength: a) M5 anorthosite warm inferior unit, b) M7 high internal heating, c) M8, low viscosity melts , d)M6 mafic granulite inferior unit. cf. Table 2 and text for details. 


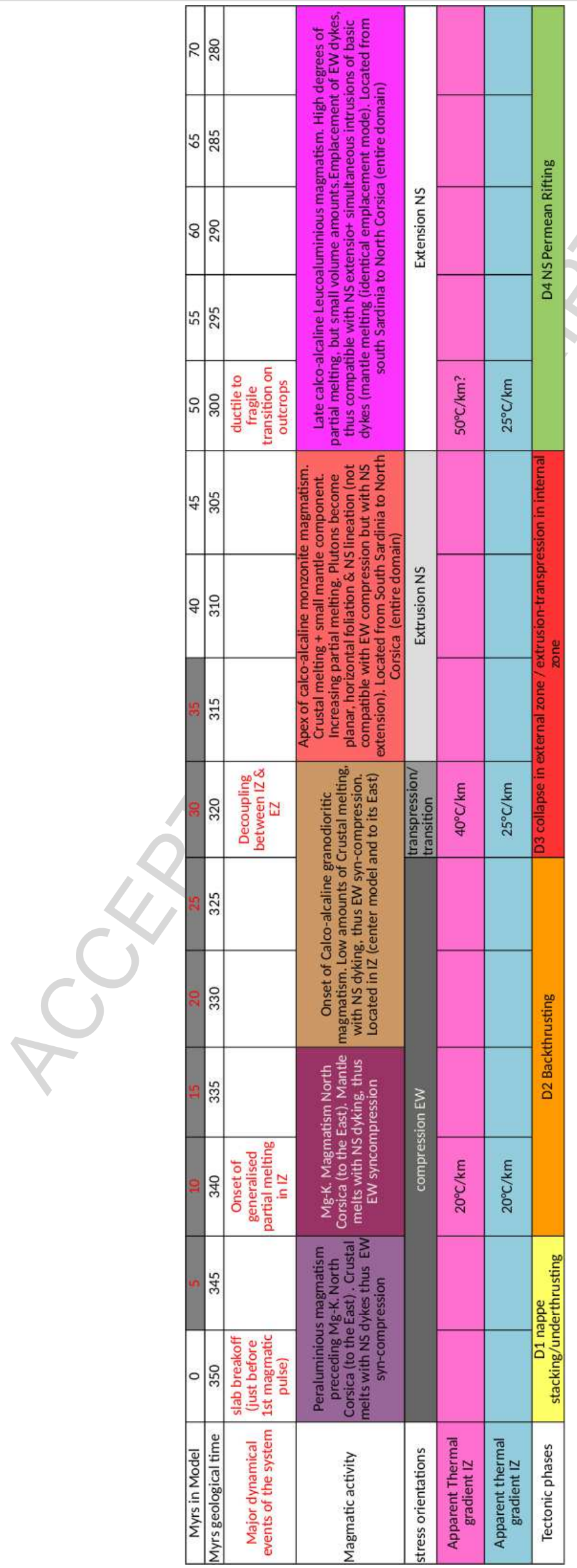

Table 1: Synthesis of thermal and mechanical evolution of the South European Variscan Belt and related magmatism (cf. 
Fig.3 and Supp Mat.). See text for details.

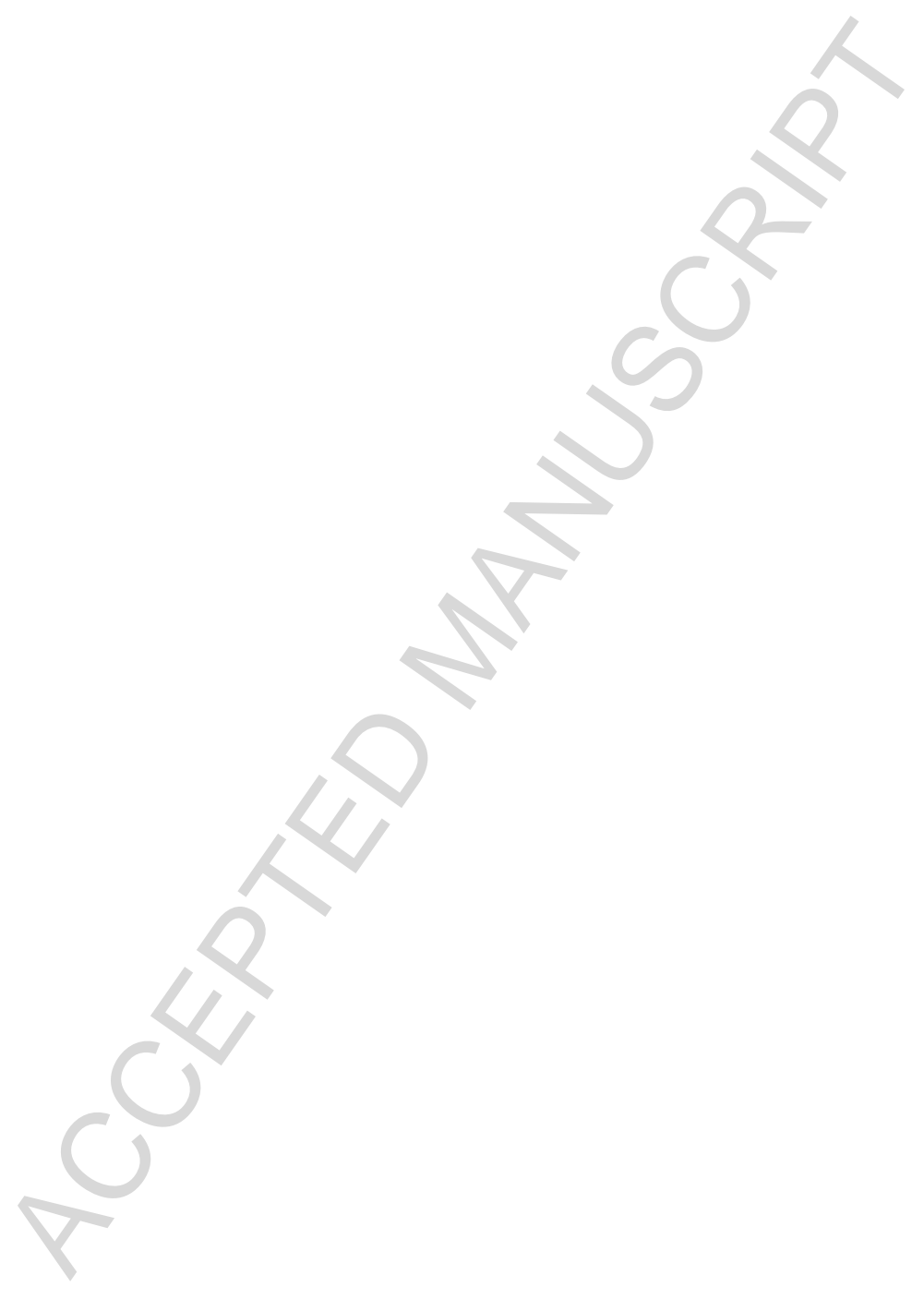


ACCEPTED MANUSCRIPT

\begin{tabular}{|c|c|c|}
\hline $\begin{array}{c}\text { Symbo } \\
1\end{array}$ & Description & Value-units \\
\hline $\mathrm{g}$ & gravity & $9.81 \mathrm{~m}^{2} / \mathrm{s}$ \\
\hline$\rho$ & density - Table 3 & $\mathrm{~kg} / \mathrm{m}^{3}$ \\
\hline $\mathrm{G}, \lambda$ & Lamé elastic constants & $30 \mathrm{GPa}$ \\
\hline$\varphi, S_{0}$ & Friction angle and cohesion for Coulomb failure & $5-20^{\circ}, 5-10 \mathrm{MPa}$ \\
\hline $\mathrm{H}_{\mathrm{p}}$ & Depth of Initial orogenic prism & $60 \mathrm{~km}$ \\
\hline $\mathrm{Vb}$ & Horizontal velocity (M0, M2, M02, M32, M37) & $\mathbf{0}, 0.5, \mathbf{2} \mathrm{cm} / \mathrm{yr}$ \\
\hline $\mathrm{Q}_{\text {। }}$ & Latent heat for melting material & $3.10^{5} \mathrm{~J} / \mathrm{kg}$ \\
\hline$\alpha_{0}$ & Reference thermal heat expansion & $3.10^{-5} / \mathrm{K}$ \\
\hline$\beta_{0}$ & Reference thermal compressibility & $10^{-11} / \mathrm{K}$ \\
\hline$C p_{0}$ & Reference heat capacity & $1000 \mathrm{~J} / \mathrm{kg} / \mathrm{C}$ \\
\hline $\mathrm{k}$ & Thermal conductivity - Table 3 & $\mathrm{~W} / \mathrm{m} /{ }^{\circ} \mathrm{C}$ \\
\hline $\mathrm{H}_{\mathrm{s}}, \mathrm{h}_{\mathrm{r}}$ & Radiogenic crustal source $H_{s}=H_{0} \exp \left(-y / h_{r}\right)(\mathbf{M 6}, M 60)$ & $10^{-9}, 8.10^{-10} \mathrm{~W} / \mathrm{kg}$ \\
\hline $\mathrm{ML}$ & Depth of isotherm $900^{\circ} \mathrm{C}$ below prism (M3, M5, M02, M32) & $70,120 \mathrm{~km}$ \\
\hline$\mu_{\min }$ & Minimum bulk viscosity cutoff for crustal material (M7, M37) & $10^{19}, 10^{20}$ Pa.s \\
\hline Tsol & Melting Temperatures (M9) & $690-740^{\circ} \mathrm{C}$ \\
\hline M & Melt f(T) & Eqs. 5-8 \\
\hline ker & Diffusion coefficient for surface processes (M4, M146) & $\begin{array}{l}200 \text { or } \mathbf{2 0 - 4 0 0} \\
\mathrm{m}^{2} / \mathrm{yr}\end{array}$ \\
\hline $\begin{array}{l}\text { A,n, } \\
Q\end{array}$ & Power law creep parameters - Table 3 (M5,M8, M55) & - \\
\hline
\end{tabular}

Table 2: Symbols and parameters used in the numerical models. Grey values are those tested in differernt models (list Table 4). 


\begin{tabular}{|c|c|c|c|c|c|c|c|c|}
\hline Layer & Rock type & $\begin{array}{c}\rho 0 \\
\mathrm{~kg} / \mathrm{m}^{3}\end{array}$ & $\begin{array}{c}\mathrm{k} \\
\mathrm{W} / \mathrm{m} /{ }^{\circ} \mathrm{C}\end{array}$ & $\begin{array}{c}\mathrm{A} \\
\left(\mathrm{MPa}^{-n} / \mathrm{s}\right)\end{array}$ & $\mathrm{n}$ & $\begin{array}{c}\mathrm{Q} \\
\mathrm{kJ} / \mathrm{mol}\end{array}$ & $\begin{array}{l}\text { Tsol } \\
{ }^{\circ} \mathrm{C}\end{array}$ & $\begin{array}{l}\text { Tfus } \\
{ }^{\circ} \mathrm{C}\end{array}$ \\
\hline Upper (Mafic) crust & Diabase & 2800 & 2.7 & $\begin{array}{l}2.0 x \\
10^{-4}\end{array}$ & 3.4 & 260 & 690 & 800 \\
\hline Mantle & Dry olivine & 3200 & 3.3 & $7.0 \times 10^{4}$ & 3.0 & 520 & - & - \\
\hline $\begin{array}{l}\text { Superior Unit } \\
\text { felsic crust }\end{array}$ & Quartz & 2800 & 2.5 & $1.0 \times 10^{-3}$ & 2.3 & 167 & $\begin{array}{l}690- \\
740\end{array}$ & 800 \\
\hline $\begin{array}{l}\text { Inferior Unit } \\
\text { felsic melange } \\
\text { mafic melange }\end{array}$ & $\begin{array}{l}\text { Quartzodiorite } \\
\text { Anorthosite } \\
\text { Mafic granulite }\end{array}$ & $\begin{array}{l}2800 \\
2900\end{array}$ & 2.7 & $\begin{array}{l}1.3 \times 10^{-3} \\
3.2 \times 10^{-4} \\
1.4 \times 10^{4}\end{array}$ & $\begin{array}{l}2.4 \\
4.2\end{array}$ & $\begin{array}{l}219 \\
238 \\
445\end{array}$ & $\begin{array}{l}690- \\
740 \\
800\end{array}$ & $\begin{array}{l}800 \\
900\end{array}$ \\
\hline Mafic crust buttress & Mafic granulite & 2900 & 2.7 & $1.4 \times 10^{4}$ & 4.2 & 445 & 800 & 900 \\
\hline $80 \%$ molten felsic crust & Wet granite & 2700 & 2.5 & $2.0 \times 10^{-4}$ & 1.9 & 137 & - & - \\
\hline $40 \%$ Molten Mafic crust & Mafic granulite & 3200 & 2.5 & $2.0 \times 10^{-4}$ & 1.9 & 137 & - & - \\
\hline
\end{tabular}

Table 3: Power law creep parameters, reference density and conductivity for all layers, cf. Rannalli (1995) and references therein. Layer in grey indicate alternative rheological composition tested in section 4.3. The two last columns depict solidus and liquidus temperatures according to melting equations 5-6. 


\begin{tabular}{|c|c|c|c|c|c|c|c|}
\hline Model Name & $\begin{array}{l}\text { Model } \\
\text { description }\end{array}$ & $\begin{array}{l}\mathrm{Fi} \\
\mathrm{g}\end{array}$ & Timing & $\begin{array}{l}\text { Thermal } \\
\text { gradient in } \\
\text { IZ after } 30 \\
\text { My }\end{array}$ & $\begin{array}{l}\text { Thermal } \\
\text { Peak in } \\
\text { IZ }\end{array}$ & $\begin{array}{l}\text { Dimensions } \\
\text { of exhumed } \\
\text { area (IZ) }\end{array}$ & $\begin{array}{l}\text { Decoupling } \\
\text { EZ and IZ }\end{array}$ \\
\hline & $\begin{array}{l}\text { Field } \\
\text { observations }\end{array}$ & & $>20 \mathrm{Ma}$ & $30-40^{\circ} \mathrm{C} / \mathrm{km}$ & $\begin{array}{l}800+/- \\
50^{\circ} \mathrm{C}\end{array}$ & $\sim 100 \mathrm{~km}$ & $\begin{array}{l}\text { West } \\
\text { dipping } \\
\text { detachemen } \\
t\end{array}$ \\
\hline $\begin{array}{l}\text { MO } \\
\text { L1V0HrB }\end{array}$ & $\mathrm{Vb}=0$. & $6 a$ & $\sqrt{20 M a}$ & $\sqrt{ } 40 \% / \mathrm{km}$ & $\sqrt{ } 850^{\circ} \mathrm{C}$ & X $80 \mathrm{~km}$ & X absent \\
\hline $\begin{array}{l}\text { M1 } \\
\text { L1Hr8HB }\end{array}$ & $\begin{array}{l}\text { Details in } \\
\text { Caption. }\end{array}$ & 5 & $\sqrt{20 M a}$ & $\sqrt{35} / \mathrm{km}$ & $\begin{array}{l}\sqrt{ } 850^{\circ} \mathrm{C} \\
\text { locally } \\
900^{\circ} \mathrm{C}\end{array}$ & $\begin{array}{l}\sqrt{100 \mathrm{~km} \text { at }} \\
10 \mathrm{~km} \text { depth }\end{array}$ & $\sqrt{\text { at } X \sim 75 \mathrm{~km}}$ \\
\hline $\begin{array}{l}\text { M2 } \\
\text { L100V1Hr8HBR } \\
\text { H }\end{array}$ & $\begin{array}{l}\mathrm{V}_{\mathrm{b}}=1 \mathrm{~mm} / \mathrm{yr} \\
\mathrm{ML}=1120 \mathrm{~km} \\
\rho_{\text {melt }}=+50 \mathrm{~kg} / \mathrm{m}^{3}\end{array}$ & $6 b$ & $\sqrt{20 M a}$ & X $30^{\circ} / \mathrm{km}$ & $\sqrt{ } 800^{\circ} \mathrm{C}$ & $\begin{array}{l}\text { X 25km } \\
\text { single } \\
\text { instability }\end{array}$ & $X$ very weak \\
\hline $\begin{array}{l}\text { M3 } \\
\text { L100RDtied }\end{array}$ & $\begin{array}{l}\mathrm{V}_{\mathrm{b}}=1 \mathrm{~cm} / \mathrm{yr} \\
\mathrm{ML}=120 \mathrm{~km} \\
\rho_{\text {melt }}=+50 \\
\mathrm{~kg} / \mathrm{m}^{3} \\
\mu_{\text {melt }}=-5.10^{19} \\
\text { Pa.s }\end{array}$ & $6 \mathrm{c}$ & X 30Ma & $\begin{array}{l}\sqrt{3} 5^{\circ} / \mathrm{km} \\
\mathrm{X} \text { sharp isobar } \\
\text { exhumation }\end{array}$ & $\sqrt{800^{\circ} \mathrm{C}}$ & X $50 \mathrm{~km}$ & $X$ very weak \\
\hline $\begin{array}{l}\text { M4 } \\
\text { CBJ0EAHr9 }\end{array}$ & $\begin{array}{l}\mathrm{k}_{\text {ero }}=500-20 \\
\mathrm{y} / \mathrm{m}^{2}\end{array}$ & $6 \mathrm{~d}$ & $\sqrt{20 M a}$ & $\sqrt{40^{\circ}} / \mathrm{km}$ & $\times 750^{\circ} \mathrm{C}$ & $\begin{array}{l}\times 20 \mathrm{~km} \\
\times 50 \mathrm{~km}\end{array}$ & $\sqrt{ }$ at $X \sim 50 \mathrm{~km}$ \\
\hline $\begin{array}{l}\text { M5 } \\
\text { L100RDhotanort } \\
\text { h }\end{array}$ & $\begin{array}{l}\mathrm{V}_{\mathrm{b}}=1 \mathrm{~cm} / \mathrm{yr} \\
\mathrm{ML}=120 \mathrm{~km} \\
\rho_{\text {melt }}=-50 \mathrm{~kg} / \mathrm{m}^{3} \\
\mu_{\text {melt }}=- \\
5.10^{19} \mathrm{~Pa} . \mathrm{s} \\
\mathrm{C}_{\text {sup }}=\text { Anorthosit } \\
\mathrm{e}^{\text {s. }}\end{array}$ & $7 a$ & X10Ma & X $30^{\circ} / \mathrm{km}$ & $\sqrt{ } 850^{\circ} \mathrm{C}$ & $\begin{array}{l}\sqrt{ } 120 \mathrm{~km} \\
X \text { not above } \\
20 \mathrm{~km}\end{array}$ & $\begin{array}{l}\text { X no } \\
\text { penetration } \\
\text { into upper } \\
\text { cr. }\end{array}$ \\
\hline $\begin{array}{l}\text { M6 } \\
\text { L1Hr9 }\end{array}$ & $\mathrm{H}_{1}=10^{-9} \mathrm{~W} / \mathrm{kg}$ & $7 \mathrm{~b}$ & $\sqrt{20 M a}$ & X $50^{\circ} / \mathrm{km}$ & $\times 1000^{\circ} \mathrm{C}$ & $\begin{array}{l}\text { X150 km too } \\
\text { broad }\end{array}$ & $\sqrt{ }$ unclear \\
\hline $\begin{array}{l}\text { M7 } \\
\text { L1vis19H }\end{array}$ & $\mu_{\min }=10^{19} \mathrm{~Pa} . \mathrm{s}$ & $7 \mathrm{c}$ & X 15Ma & $\begin{array}{l}\sqrt{ } 35^{\circ} / \mathrm{km} \\
\text { X stabilizes at } \\
<25^{\circ} \mathrm{C} / \mathrm{km}\end{array}$ & $\sqrt{820^{\circ} \mathrm{C}}$ & $\sqrt{100 \mathrm{~km}}$ & $\begin{array}{l}\sqrt{ } \text { at } \\
X \sim 70 \mathrm{~km}\end{array}$ \\
\hline $\begin{array}{l}\text { M8 } \\
\text { fels4maf314 }\end{array}$ & $\mathrm{C}_{\text {Inf }}=$ Maf. Gran & $7 d$ & $\sqrt{20 M a}$ & $\sqrt{40} / \mathrm{km}$ & $\sqrt{880^{\circ} \mathrm{C}}$ & $\begin{array}{l}\text { X100km, } \\
\text { capped low } \\
\text { melts }\end{array}$ & $\begin{array}{l}\sqrt{\text { at }} \\
X \sim 50 \mathrm{~km}\end{array}$ \\
\hline
\end{tabular}

Table 4: Models characteristics. The refence model M1 in shaded gray has the following parameters: boundary velocity $V_{b}=0.5 \mathrm{~cm} / \mathrm{yr}$, Erosion coefficient $\mathrm{k}_{\text {ero }}=200 \mathrm{~m}^{2} / \mathrm{yr}$, depth of isotherm $900^{\circ} \mathrm{C}$ below the orogen $\mathrm{ML}=70 \mathrm{~km}$, Radiogenic heat production $\mathrm{H} 1=\mathrm{H} 0=8.10^{-}{ }^{10} \mathrm{~W} / \mathrm{kg}$, interface shear heating Hs over 5 $\mathrm{km}$ width and with a shear stress $5 \mathrm{MPa}$, minimal viscosity $\mu_{\min }=5.10^{19}$ Pa.s, Melting condition for felsic units $\mathrm{T}_{\text {sol }}=690^{\circ} \mathrm{C}$, Felsic Superior Unit rheology $\mathrm{C}_{\text {sup }}=$ Quarztodiorite (cf. Table 3, orange layer), Inferior unit rheology $\mathrm{C}_{\text {inf }}=$ Anorthosite (blue and green layers). The fistt column describes the parameters that differ from this reference model M1. Relative changes in density and viscosity of molten material are indicated with $\rho_{\text {melt }}$ and $\mu_{\text {melt }}$. Columns 4-8 describe how each model fits or not the MTM field data (top line). 
HIGHLIGHTS:

* A geological synthesis and thermo-mechanical models of the South Variscan belt,

* the orogenic root exhumed diapirically during convergence for $20 \mathrm{My}$ over $>100 \mathrm{~km}^{2}$,

*A continuous transition from continental collision to perpendicular extension,

* Models fit data with $0.5 \mathrm{~cm} / \mathrm{yr}$ convergence and mostly internal heating,

*Alternation of felsic crustal units against mafic buttress is necessary,

${ }^{*} \mathrm{~A}$ viscosity of $10^{2} \square$ Pa.s appropriately simulates the rise of partially molten mush. 